\title{
Dietary Sodium and Potassium Intake: Data from the Mexican National Health and Nutrition Survey 2016
}

\author{
Jorge Vargas-Meza, Manuel A. Cervantes-Armenta, Ismael Campos-Nonato, ${ }^{*}$ Claudia Nieto, Joaquín Alejandro \\ Marrón-Ponce, Simón Barquera, Mario Flores-Aldana, Sonia Rodríguez-Ramírez
}

Center for Nutrition and Health Research, National Institute of Public Health, Cuernavaca, Mexico. Affiliation

* Correspondence: icampos@insp.mx. Av. Universidad 655 Col Santa María Ahuacatitlán C.P. 62100. Morelos, México. (I.C.N.)

\begin{abstract}
:
Population studies have demonstrated an association between sodium $(\mathrm{Na})$ and potassium (K) intake and levels of blood pressure (BP) and cholesterol. The aim of this study was to describe the dietary intake and distribution of $\mathrm{Na}$ and $\mathrm{K}$ in Mexicans, and their association with metabolic risk outcomes. We analyzed a national survey that included 4,219 participants. Dietary information was obtained through a 24 -hour recall. Foods and beverages were classified based on the degree of processing. BP and biomarkers in blood and urine were measured. The mean intake $(\mathrm{mg} / \mathrm{d})$ of Na was 1512 in pre-schoolchildren, 2844 in schoolchildren, 3743 in adolescents, and 3132 in adults. The mean intake of $\mathrm{K}$ was 1616 in pre-schoolchildren, 2256 in schoolchildren, 2967 in adolescents, and 3401 in adults. Processed and ultra-processed foods (UPF) contribute to sodium intake: $49 \%$ in preschool and schoolchildren, $47 \%$ in adolescents, and $39 \%$ in adults. Adults in the fourth quartile of sodium intake had lower serum concentrations of cholesterol $(181.4 \mathrm{mg} / \mathrm{dL})$ and HDLc $(35.5 \mathrm{mg} / \mathrm{dL})$. The Mexican population has high $\mathrm{Na}$ and low $\mathrm{K}$ intakes. There is a relationship between Na sodium consumption and cholesterol, and LDL levels. UPF contributes to almost $40 \%$ of the sodium consumed by Mexicans.
\end{abstract}

Keywords: Sodium, potassium, national survey, Mexico

\section{Introduction}

Sodium (Na) and Potassium $(\mathrm{K})$ are essential minerals for human homeostasis because they help maintain osmotic balance [1]. In the plasma membrane of cells, $\mathrm{Na}$ and $\mathrm{K}$ move against concentration gradients through constant pumping of Na-K ATPase. This ion exchange regulates cell volume and maintains homeostasis of tissues and organs [2].

Population studies have demonstrated an association between high dietary Na intake and high blood pressure (BP) [3], reduced renal function [4] and metabolic disorders [5]. Conversely, a low Na intake can lower BP in people who are sensitive to salt, increase the vascular insulin resistance, and improve blood levels of cholesterol and triglycerides [6].

The Institute of Medicine (IOM) established a maximum tolerable intake level (UL) of $\mathrm{Na}$ of $2.3 \mathrm{~g} /$ day [7], while the World Health Organization (WHO) recommends not exceeding $2 \mathrm{~g} /$ day [8]. Both organizations suggest that consuming less than these amounts is unlikely to cause adverse health effects for most people in the general population [9]. In a cohort conducted in Mexicans, the mean Na intake was $3.5 \mathrm{~g} / \mathrm{day}$ [10]. In a study that examined sodium levels in 14 Latin American and Caribbean countries that included Mexico, the main dietary sources of $\mathrm{Na}$ were meat and processed meats, readyto-eat cereals, yogurt and milk-based drinks, seasonings, and salty snacks [11].

The NOVA classification classifies foods according to the degree of their processing [12]. Processed and ultra-processed foods (UPF) are characterized by containing high 
amounts of $\mathrm{Na}$ [12]. According to the Centers for Disease Control and Prevention (CDC), up to $40 \%$ of daily sodium intake comes from UPF [13]. In Mexico, the purchase of these foods has increased during the last decades [14]; however, the contribution of these foods to daily sodium intake is unknown.

On the other hand, an increase in $\mathrm{K}$ intake has beneficial effects on cardiovascular health outcomes, such as lower BP and lower risk of renal disease [6,15]. However, $\mathrm{K}$ is among the four most common deficient nutrients in the diet $[10,16]$, and an adequate intake (at least $3.5 \mathrm{~g} /$ day) [7,8] has been regarded as a protective factor against high BP and kidney failure [17]. In contrast, a low intake of $\mathrm{K}$ increases deleterious effect of $\mathrm{Na}$ on $\mathrm{BP}$ [18].

Adult $\mathrm{K}$ intake was found to be low $(1.9 \mathrm{~g} / \mathrm{d})$ in a cohort based in Mexico City [10]. The WHO highlights the importance of implementing a surveillance system to measure and evaluate the patterns of salt consumption, as well as identify the main sources of $\mathrm{Na}$ consumption in the population, since this can inform the development of programs aimed at reducing $\mathrm{Na}$ consumption [19]. The effects of high sodium and low potassium intake on cardiovascular disease (CVD) are synergic, so the $\mathrm{Na}-\mathrm{K}$ ratio may be a strong indicator for cardiovascular health outcomes [20,21]. The current evidence indicates that a ratio greater than 1.0 between $\mathrm{Na}$ and $\mathrm{K}$ results in an increase in BP [22].

In Mexico, the consumption of $\mathrm{Na}$ and $\mathrm{K}$, as well as their food sources, have not been reported with nationally representative data. Therefore, the aim of this study was to describe the dietary intake and main food sources of $\mathrm{Na}$ and $\mathrm{K}$ in participants of the Mexican National Health and Nutrition Survey 2016 (ENSANUT-2016). A secondary objective was to describe the intake distribution of dietary $\mathrm{Na}$ and $\mathrm{K}$ in the Mexican population according to the NOVA classification. A third objective was to describe the association between $\mathrm{Na}$ and $\mathrm{K}$ intake with metabolic risk outcomes in adults.

\section{Materials and Methods}

2.1 Design and study population.

This cross-sectional study used data from the ENSANUT-2016, which is a probabilistic survey with national, regional (North, Center, Mexico City and South), and urban (with $\geq 2,500$ inhabitants) and rural $(<2,500$ inhabitants) strata representativeness. The main objective of ENSANUT-2016 was to quantify the frequency and distribution of health and nutrition conditions in the Mexican population, as well as associated risk factors. The period of data collection was between May and October 2016. Details of the design, sampling size calculation, and methodology of this survey have been previously described elsewhere [23].

\subsection{Estimating total sodium and potassium intake}

Dietary information was obtained from a subsample of $\approx 26 \%$ participants of ENSANUT-2016. It included 4,305 subjects, of which 535 were pre-school children ( 1 to $<5$ years), 1,101 were school-age children ( 5 to $<12$ years), 1,284 were adolescents (12 to $<20$ years), and 1,421 were adults ( $>20$ years).

Trained interviewers obtained a multiple-pass 24-hour recall [24]. The recall was collected between Monday and Sunday to capture the intake variability between weekdays and weekends. Participants, particularly those younger than 15 years old, were assisted by the person who cooked and prepared their meals in the household. Those participants with extreme energy intake (outside three standard deviations of the log of energy intaketo-energy requirement ratio), were excluded from the study, as well as pregnant, lactating females, and all males $\geq 1$ years old $(n=184)$ [25]. Energy and nutrient intakes were estimated using the Mexican Food Database (BAM for its Spanish acronym, version 1.1) [26].

Participants reported their dietary intake from the previous days as individual foods, custom recipes (individual ingredients that make up the recipe), and standard recipes 
(sets of default ingredients that make up a recipe when the informer was not able to pro- 100 vide one). For the present analysis, food recipes were disaggregated into their ingredients. 101 The ENSANUT-2016 dataset does not include Na from salt added at the table but does 102 include $\mathrm{Na}$ from salt used in preparations.

We classified all foods and beverages that were reported into 36 groups according to their nutritional profile; if they were frequently consumed by the population, these were considered in a single group (for example, tortilla). The groups are shown in supplementary table 1 . We calculated the total $\mathrm{Na}$ and $\mathrm{K}$ intake and the contribution (percentage of total $\mathrm{Na} / \mathrm{k}$ intake) of each food group, meal times, and ratio of sodium to potassium intake (sodium: potassium). 
Table 1. Sodium and potassium intake by sociodemographic characteristics and BMI in Mexican population. ENSANUT 2016.

\begin{tabular}{|c|c|c|c|c|c|c|c|c|}
\hline & \multicolumn{2}{|c|}{ Pre-Schoolchildren } & \multicolumn{2}{|c|}{ Schoolchildren } & \multicolumn{2}{|c|}{ Adolescents } & \multicolumn{2}{|c|}{ Adults } \\
\hline & $n=528$ & $\mathrm{~N}=8,584,831$ & $\mathrm{n}=1095$ & $\mathrm{~N}=16,144,480$ & $\mathrm{n}=1240$ & $\mathrm{~N}=23,988,992$ & $\mathrm{n}=1356$ & $\mathrm{~N}=87,921,191$ \\
\hline & Mean (SE) & $95 \% \mathrm{CI}$ & Mean (SE) & $95 \% \mathrm{CI}$ & Mean (SE) & $95 \% \mathrm{CI}$ & Mean (SE) & $95 \% \mathrm{CI}$ \\
\hline \multicolumn{9}{|l|}{ Total $(n=4,219 ; \mathrm{N}=136,639,494)$} \\
\hline Sodium intake (mg/day) & $1512.2 \pm 68.6$ & $(1377.1,1647.2)$ & $2843.8 \pm 236.1$ & $(2379.0,3308.6)$ & $3743.2 \pm 304.2$ & $(3144.4,4341.9)$ & $3132.3 \pm 171.9$ & $(2794.0,3470.7)$ \\
\hline Potassium intake (mg/day) & $1615.7 \pm 68.6$ & $(1480.6,1750.7)$ & $2255.7 \pm 136.5$ & $(1986.9,2524.5)$ & $2966.6 \pm 180.3$ & $(2611.7,3321.5)$ & $3400.6 \pm 273.5$ & $(2862.1,3939.0)$ \\
\hline $\mathrm{Na} / \mathrm{K}$ ratio & $1.1 \pm 0.1$ & $(0.9,1.2)$ & $1.4 \pm 0.1$ & $(1.1,1.7)$ & $1.3 \pm 0.0$ & $(1.3,1.4)$ & $1.1 \pm 0.0$ & $(1.0,1.2)$ \\
\hline \multicolumn{9}{|l|}{ Sex } \\
\hline \multicolumn{9}{|l|}{ Women $(n=2,312 ; \mathrm{N}=72,673,426)$} \\
\hline Sodium intake (mg/day) & $1494.8 \pm 95.6$ & $(1306.7,1682.9)$ & $2817.2 \pm 425.6$ & $(1979.5,3655.0)$ & $3286.6 \pm 240.2$ & $(2813.8,3759.5)$ & $2927.9 \pm 217.2$ & $(2500.3,3355.5)$ \\
\hline Potassium intake (mg/day) & $1594.4 \pm 93.0$ & $(1411.3,1777.6)$ & $2052.2 \pm 77.6$ & $(1899.4,2205.1)$ & $2560.6 \pm 138.5$ & $(2288.0,2833.1)$ & $3250.5 \pm 427.4$ & $(2409.1,4091.9)$ \\
\hline $\mathrm{Na} / \mathrm{K}$ ratio & $1.0 \pm 0.1$ & $(0.9,1.1)$ & $1.6 \pm 0.3$ & $(1.0,2.2)$ & $1.4 \pm 0.1$ & $(1.2,1.5)$ & $1.1 \pm 0.1$ & $(1.0,1.2)$ \\
\hline \multicolumn{9}{|l|}{ Men $(n=1,907 ; N=63,966,069)$} \\
\hline Sodium intake (mg/day) & $1528.6 \pm 109.7$ & $(1312.5,1744.6)$ & $2867.2 \pm 253.4$ & $(2368.3,3366.1)$ & $4236.6 \pm 567.5$ & $(3119.5,5353.7)$ & $3383.7 \pm 257.2$ & $(2877.3,3890.1)$ \\
\hline Potassium intake (mg/day) & $1635.8 \pm 96.6$ & $(1445.6,1826.0)$ & $2434.6 \pm 236.4$ & $(1969.2,2900.0)$ & $3405.5 \pm 329.3$ & $(2757.1,4053.9)$ & $3585.0 \pm 325.7$ & $(2943.7,4226.3)$ \\
\hline $\mathrm{Na} / \mathrm{K}$ ratio & $1.1 \pm 0.1$ & $(0.9,1.4)$ & $1.3 \pm 0.1$ & $(1.2,1.4)$ & $1.3 \pm 0.1$ & $(1.2,1.5)$ & $1.1 \pm 0.1$ & $(1.0,1.2)$ \\
\hline \multicolumn{9}{|l|}{ Area of residence } \\
\hline \multicolumn{9}{|l|}{ Rural $(\mathrm{n}=2,227 ; \mathrm{N}=37,106,754)$} \\
\hline Sodium intake (mg/day) & $1439.1 \pm 107.6$ & $(1225.8,1652.3)$ & $2515.5 \pm 243.5$ & $(2032.9,2998.1)$ & $3498.7 \pm 202.9$ & $(3096.6,3900.8)$ & $3133.7 \pm 375.8$ & $(2389.0,3878.5)$ \\
\hline Potassium intake (mg/day) & $1552.4 \pm 100.4$ & $(1353.5,1751.3)$ & $2193.2 \pm 125.1$ & $(1945.2,2441.1)$ & $2817.7 \pm 135.3$ & $(2549.5,3085.9)$ & $3626.9 \pm 452.4$ & $(2730.3,4523.5)$ \\
\hline $\mathrm{Na} / \mathrm{K}$ ratio & $1.0 \pm 0.1$ & $(0.9,1.1)$ & $1.3 \pm 0.1$ & $(1.1,1.5)$ & $1.3 \pm 0.1$ & $(1.2,1.4)$ & $1.0 \pm 0.1$ & $(0.9,1.2)$ \\
\hline \multicolumn{9}{|l|}{ Urban $(n=1,992 ; N=99,532,740)$} \\
\hline Sodium intake (mg/day) & $1538.7 \pm 84.6$ & $(1371.7,1705.7)$ & $2978.9 \pm 317.6$ & $(2352.0,3605.9)$ & $3824.4 \pm 398.5$ & $(3037.9,4610.9)$ & $3131.8 \pm 189.5$ & $(2757.7,3505.9)$ \\
\hline Potassium intake (mg/day) & $1638.7 \pm 85.9$ & $(1469.0,1808.3)$ & $2281.4 \pm 185.6$ & $(1915.1,2647.7)$ & $3016.1 \pm 233.3$ & $(2555.6,3476.6)$ & $3314.9 \pm 337.7$ & $(2648.4,3981.5)$ \\
\hline $\mathrm{Na} / \mathrm{K}$ ratio & $1.1 \pm 0.1$ & $(0.9,1.3)$ & $1.5 \pm 0.2$ & $(1.1,1.9)$ & $1.4 \pm 0.1$ & $(1.2,1.5)$ & $1.1 \pm 0.1$ & $(1.0,1.2)$ \\
\hline \multicolumn{9}{|l|}{ Socioeconomic Tertile } \\
\hline \multicolumn{9}{|l|}{ Low $\quad(\mathrm{n}=1,464 ; \mathrm{N}=31,441,350)$} \\
\hline Sodium intake (mg/day) & $1388.4 \pm 112.4$ & $(1166.7,1610.2)$ & $2368.8 \pm 201.1$ & $(1972.1,2765.5)$ & $2896.1 \pm 144.7$ & $(2610.7,3181.6)$ & $2854.5 \pm 278.6$ & $(2304.9,3404.2)$ \\
\hline
\end{tabular}




\begin{tabular}{|c|c|c|c|c|c|c|c|c|}
\hline Potassium intake (mg/day) & $1483.7 \pm 101.0$ & $(1284.4,1683.0)$ & $2163.3 \pm 250.4$ & $(1669.3,2657.3)$ & $2701.7 \pm 134.7$ & $(2436.1,2967.4)$ & $3283.7 \pm 261.1$ & $(2768.6,3798.8)$ \\
\hline $\mathrm{Na} / \mathrm{K}$ ratio & $1.0 \pm 0.1$ & $(0.9,1.2)$ & $1.3 \pm 0.1$ & $(1.1,1.4)$ & $1.2 \pm 0.0$ & $(1.1,1.3)$ & $1.0 \pm 0.1$ & $(0.8,1.1)$ \\
\hline \multicolumn{9}{|l|}{ Medium ( $\mathrm{n}=1,516 ; \mathrm{N}=40,785,812)$} \\
\hline Sodium intake (mg/day) & $1448.3 \pm 108.6$ & $(1234.3,1662.2)$ & $2958.1 \pm 574.0$ & $(1827.6,4088.7)$ & $4324.4 \pm 772.5$ & $(2802.8,5846.0)$ & $3264.8 \pm 379.6$ & $(2517.0,4012.6)$ \\
\hline Potassium intake (mg/day) & $1637.2 \pm 118.2$ & $(1404.3,1870.1)$ & $1982.8 \pm 116.5$ & $(1753.3,2212.4)$ & $3423.6 \pm 445.3$ & $(2546.4,4300.8)$ & $3450.6 \pm 486.4$ & $(2492.6,4408.7)$ \\
\hline $\mathrm{Na} / \mathrm{K}$ ratio & $1.1 \pm 0.2$ & $(0.8,1.4)$ & $1.7 \pm 0.4$ & $(0.9,2.5)$ & $1.3 \pm 0.1$ & $(1.1,1.5)$ & $1.2 \pm 0.1$ & $(1.0,1.3)$ \\
\hline \multicolumn{9}{|l|}{ High $(n=1,239 ; N=64,412,333)$} \\
\hline Sodium intake (mg/day) & $1684.5 \pm 126.3$ & $(1435.7,1933.3)$ & $3053.3 \pm 313.5$ & $(2435.7,3670.9)$ & $3707.6 \pm 271.0$ & $(3173.6,4241.5)$ & $3186.0 \pm 216.4$ & $(2759.6,3612.4)$ \\
\hline Potassium intake (mg/day) & $1692.7 \pm 123.8$ & $(1448.7,1936.6)$ & $2546.4 \pm 264.9$ & $(2024.6,3068.3)$ & $2745.9 \pm 132.0$ & $(2485.8,3005.9)$ & $3426.1 \pm 463.0$ & $(2513.8,4338.4)$ \\
\hline $\mathrm{Na} / \mathrm{K}$ ratio & $1.1 \pm 0.1$ & $(1.0,1.3)$ & $1.3 \pm 0.1$ & $(1.1,1.4)$ & $1.5 \pm 0.1$ & $(1.3,1.6)$ & $1.1 \pm 0.1$ & $(1.0,1.3)$ \\
\hline \multicolumn{9}{|l|}{ Body Mass Index a } \\
\hline \multicolumn{9}{|c|}{ Normal $\quad(n=2,277 ; N=49,562,419)$} \\
\hline Sodium intake (mg/day) & $1477.9 \pm 70.7$ & $(1338.6,1617.1)$ & $2533.5 \pm 327.7$ & $(1888.3,3178.7)$ & $2894.7 \pm 121.6$ & $(2655.2,3134.1)$ & $2898.6 \pm 234.6$ & $(2436.6,3360.5)$ \\
\hline Potassium intake (mg/day) & $1576.3 \pm 73.3$ & $(1431.9,1720.6)$ & $1878.3 \pm 77.0$ & $(1726.8,2029.9)$ & $2380.0 \pm 93.7$ & $(2195.5,2564.5)$ & $3072.9 \pm 285.5$ & $(2510.8,3635.0)$ \\
\hline $\mathrm{Na} / \mathrm{K}$ ratio & $1.1 \pm 0.1$ & $(0.9,1.2)$ & $1.5 \pm 0.2$ & $(1.1,1.9)$ & $1.4 \pm 0.1$ & $(1.2,1.5)$ & $1.1 \pm 0.1$ & $(0.9,1.3)$ \\
\hline \multicolumn{9}{|c|}{ Overweight $\quad(n=949 ; N=35,937,427)$} \\
\hline Sodium intake (mg/day) & $1097.8 \pm 128.3$ & $(845.2,1350.4)$ & $2376.3 \pm 139.2$ & $(2102.2,2650.4)$ & $2856.8 \pm 138.7$ & $(2583.6,3129.9)$ & $3110.9 \pm 318.0$ & $(2484.5,3737.3)$ \\
\hline Potassium intake (mg/day) & $1064.5 \pm 153.1$ & $(762.9,1366.1)$ & $2103.3 \pm 106.4$ & $(1893.7,2312.9)$ & $2188.1 \pm 108.7$ & $(1973.9,2402.2)$ & $3163.4 \pm 400.8$ & $(2374.1,3952.7)$ \\
\hline $\mathrm{Na} / \mathrm{K}$ ratio & $1.1 \pm 0.1$ & $(0.8,1.3)$ & $1.2 \pm 0.1$ & $(1.1,1.4)$ & $1.4 \pm 0.1$ & $(1.3,1.5)$ & $1.1 \pm 0.1$ & $(1.0,1.3)$ \\
\hline \multicolumn{9}{|l|}{ Obesity $\quad(n=840 \mathrm{~N}=42,639,888)$} \\
\hline Sodium intake (mg/day) & $2194.8 \pm 254.5$ & $(1693.5,2696.2)$ & $2720.2 \pm 224.5$ & $(2277.9,3162.5)$ & $3359.6 \pm 375.0$ & $(2620.7,4098.4)$ & $3287.1 \pm 257.1$ & $(2780.5,3793.6)$ \\
\hline Potassium intake (mg/day) & $2102.1 \pm 131.4$ & $(1843.1,2361.0)$ & $2095.6 \pm 168.8$ & $(1763.1,2428.1)$ & $2653.8 \pm 252.6$ & $(2156.2,3151.5)$ & $3786.6 \pm 511.3$ & $(2779.3,4793.9)$ \\
\hline $\mathrm{Na} / \mathrm{K}$ ratio & $1.1 \pm 0.2$ & $(0.8,1.5)$ & $1.5 \pm 0.1$ & $(1.2,1.7)$ & $1.3 \pm 0.2$ & $(1.0,1.6)$ & $1.0 \pm 0.1$ & $(0.9,1.2)$ \\
\hline
\end{tabular}

Bold numbers means statistically significant difference vs reference category $(\mathrm{p}<0.05)$.

The reference category is the first row of each variable, except for the first variable where it is the first column.

a Body mass index (BMI): $<25 \mathrm{~kg} / \mathrm{m} 2$ (normal); $25-29.9 \mathrm{~kg} / \mathrm{m} 2$ (overweight); $\geq 30 \mathrm{~kg} / \mathrm{m} 2$ (obesity). For those under 19 years of age, the BMI for age was used according to the WHO child growth patterns. 


\subsection{Food Classification Based on the Degree of Processing}

Based on the NOVA food framework, foods and beverages reported in the $24 \mathrm{HR}$ interview were classified as: 1 ) unprocessed or minimally processed foods (those obtained directly from nature or altered in ways that do not introduce any additional substances but may involve removal of inedible parts); 2) processed culinary ingredients (substances derived from foods or nature through methods such as pressing, refining, grinding, milling, and drying and which are used in culinary preparations); 3 ) processed foods (those manufactured products made by adding sugar, fat, oil, salt and/or other culinary ingredients to minimally processed foods); and 4) ultra-processed foods (manufactured formulations made from substances derived from foods or synthesized from other organic sources, preservatives and additives) [12,27]. Details of the food and beverage subcategory of each NOVA group are described elsewhere [28].

\subsection{Sociodemographic characteristics and Socio Economic Index}

Trained personnel applied questionnaires to participants. The questionnaires were previously validated to collect sociodemographic characteristics. Age groups were classified as following: preschoolers ( 0 to 4.9 years), school age children (5 to 11.9 years), adolescents (12 to 19.9 years), and adults (older than 20 years). Sociodemographic characteristics such as: household characteristics, goods, and services available were used to create a socioeconomic status index (SES) using principal component analysis. The SES was classified into three categories using the $33 \%$ and $67 \%$ percentiles of the index as cutoff points to create the low, medium and high strata for SES [29].

\subsection{Anthropometry}

Trained personnel measured participants' weight, height, and waist circumference using international protocols [23]. Weight in $\mathrm{kg}$ and height in $\mathrm{m}^{2}$ were used to calculate the Body Mass Index (BMI) and categorized according to the WHO criteria [30]. For participants $<19$ years, we used STATA macro to analyze survey anthropometric data. For adult participants (>19 years), we used the following classification: Normal BMI (18.5-24.9 $\mathrm{kg} / \mathrm{m} 2)$, overweight $(25.0-29.9 \mathrm{~kg} / \mathrm{m} 2)$, obesity $(\geq 30.0 \mathrm{~kg} / \mathrm{m} 2)$.Abdominal obesity was defined as a waist circumference of $\geq 80$ and $\geq 90 \mathrm{~cm}$ for women and men, respectively [31].

\subsection{Adult sample}

Blood pressure (BP). BP was measured using a digital sphygmomanometer Omron HEM-907 XL following the protocol recommended by the American Heart Association [32]. Adults were classified with hypertension when they had a systolic $\mathrm{BP} \geq 130 \mathrm{mmHg}$ and/or a diastolic BP $\geq 85 \mathrm{mmHg}$ and/or when they were under pharmacologic treatment for high BP.

Serum biomarkers. Blood samples were collected after $\geq 8$ hours of fasting. Serum biomarkers were analyzed using the Syncron ${ }^{\circledR}$ Clinical UniCel DxC 600 system. Glucose, total cholesterol, triglycerides, HDL cholesterol (c-HDL), and LDL cholesterol (c-LDL) were analyzed by end-point coupled methods. Impaired fasting glucose was defined according to the American Diabetes Association classification [33]: Prediabetes (fasting glucose $\geq 100 \mathrm{y}<126 \mathrm{mg} / \mathrm{dL}$ or $\mathrm{HbA} 1 \mathrm{c} \geq 5.7$ and $<6.5 \%$ ) or survey finding (fasting glucose $\geq 126$ $\mathrm{mg} / \mathrm{dL}$ or $\mathrm{HbA} 1 \mathrm{c} \geq 6.5 \%$ ).

Biomarkers in urine. An $11 \mathrm{ml}$ spot urine sample was collected in a conical plastic tube. The sample was collected at the participant's home and was subsequently refrigerated $\left(2-8^{\circ} \mathrm{C}\right)$ for a maximum of 7 days. Afterwards, they were frozen at $-70^{\circ} \mathrm{C}$ until they were processed in the Mexican National Institute of Public Health (MNIPH) laboratory. Creatinine was measured by the Jaffé method and $\mathrm{Na}$ and $\mathrm{K}$ were measured through in- 
direct potentiometry with specific electrodes for the analyte and a Na glass electrode. Serum creatinine level was obtained from subjects to evaluate their kidney function alteration, which was calculated through the Chronic Kidney Disease Epidemiology Collaboration (CKD-EPI) equation [34] based on the Glomerular filtration rate (GFR, $\mathrm{ml} / \mathrm{min} / 1.73 \mathrm{~m} 2)$. It was categorized as follows: Normal $(\geq 90)$; mildly reduced (60-89); moderately reduced (30-59); severely reduced (15-29) [34]. A spot urine sample was collected among adults that had a blood sample, also in the participant's household. Women on their menstrual period or those who reported transvaginal bleeding were excluded.

Chronic diseases. An adult participant was considered to have diabetes, hypertension, cardiovascular disease, and/or acute myocardial infarction/angina pectoris when they reported the diagnosis by a doctor.

\subsection{Ethical considerations}

All participants signed the informed consent approved by the Institutional Review Board of the National Institute of Public Health in Mexico. This study was a secondary data analysis. Ethics and Research Commissions of the MNIPH with the Commission number 1401, Bioethics registration 17 CEI00120130424, and COFEPRIS registration CEI 1700736 approved the original protocol.

\subsection{Statistical Analysis}

Means, standard deviations, and confidence intervals (CI 95\%) of total Na and K intakes were estimated considering age group categories, socioeconomic index for the entire sample, academic level, residence area, BMI, BP, diabetes, cholesterol, c-LDL, c-HDL, triglycerides, and previous medical diagnosis. We also estimated means and percentage contribution of food groups and classified them by degree of processing and eating occasions, stratified by age group. The quartiles of $\mathrm{Na}$ and $\mathrm{K}$ intake were categorized by BMI, waist circumference, BP, lipids, glucose, previous medical diagnosis and smoking. We obtained the percentage and $95 \% \mathrm{CI}$ of the population with a high sodium intake, a low potassium intake, as well as a ratio $>1.0$ according to the sociodemographic characteristics.

Pearson's chi-squared tests were used to compare prevalences among strata and were carried out for multiple comparisons. A general $\mathrm{p}<0.05$ value was considered to set the statistical significance. All the analyses were performed using the SVY module for survey design in STATA version 15 (College Station, TX, USA) ${ }^{1}$

\section{Results}

Data from 4,219 participants were analyzed, representing more than 136 million Mexicans. Table 1 shows $\mathrm{Na}$ and $\mathrm{K}$ intake according to age group and sociodemographic characteristics. The mean intake of $\mathrm{Na}$ in pre- schoolchildren was $1512 \mathrm{mg}$ (95\% CI: 1 377, 1 647); in schoolchildren it was $2844 \mathrm{mg}$ (95\% CI: 2 379, 3 309); in adolescents (the age group with the highest consumption) it was $3743 \mathrm{mg}$ (95\% CI: 3 144, 4 341); and in adults it was $3132 \mathrm{mg}$ (95\% CI: 2 794, 3 470). The mean intake of $\mathrm{K}$ in pre-schoolchildren was $1616 \mathrm{mg}$ (95\% CI: 1 481, 1 751); in schoolchildren it was 2256 (95\% CI: 1 987, 2,525); in adolescents $2,967 \mathrm{mg}$ (95\% CI: 2,612, 3,322), and in adults (age group with the highest consumption) it was $3401 \mathrm{mg}$ (95\% CI: 2 862, 3 939). The Na/K ratio was higher in children 1.4 (95\% CI: $1.1,1.7)$ and adolescents 1.3 (95\% CI: $1.3,1.4)$. 
Table 2 shows the ten food groups that contribute the most to sodium and potassium intake in Mexicans, categorized by age groups. The foods groups that contributed the highest proportion to daily $\mathrm{Na}$ intake in preschool children were: Dairy (197 mg), processed meats (148 mg), and condiments (77 mg); in school-age children: Dairy (229 $\mathrm{mg})$, processed meats $(237 \mathrm{mg})$ and salty snacks $(117 \mathrm{mg})$; in adolescents: Dairy $(287 \mathrm{mg})$, processed meats (269 mg) and salty snacks (172 mg); and in adults: Red meat (197 mg), dairy (184 mg) and processed meat $(179 \mathrm{mg})$. Also by age group, the food categories that contributed to a higher daily intake of $\mathrm{K}$ in pre-school children were: Dairy (397 mg), fruits (261 mg) and vegetables (169 mg); in school-age children they were: Vegetables (350 mg), dairy $324 \mathrm{mg}$ ), fruits (2798 mg) and corn tortillas (216 mg); in adolescents they were: Fruits (415 mg), vegetables (386 mg) and corn tortillas (363 mg); and in adults they were: Vegetables (702 mg), fruits (467 mg) and corn tortillas (401 mg).

Supplementary Table 2 shows the $\mathrm{Na}$ and $\mathrm{K}$ consumption categorized by six mealtimes in the Mexican population. In preschool children, school children, adolescents and adults, the fourth meal time (fourth time in the day) had the highest daily intake of sodium (446.6 mg, $1103.4 \mathrm{mg}, 1104.4 \mathrm{mg}$ and $1114.6 \mathrm{mg}$, respectively) and K (411.3 mg, $706.9 \mathrm{mg}$, $922.0 \mathrm{mg}$ and $1208.8 \mathrm{mg}$, respectively). 
Table 2. Dietary top ten food and beverage groups contributing to sodium and potassium intake in Mexican population: ENSANUT 2016

\begin{tabular}{|c|c|c|c|c|c|c|c|c|c|c|c|c|}
\hline Sodium & \multicolumn{3}{|c|}{ Pre-Schoolchildren } & \multicolumn{3}{|c|}{ Schoolchildren } & \multicolumn{3}{|c|}{ Adolescents } & \multicolumn{3}{|c|}{ Adults } \\
\hline Ranking & Food groups & $\mathrm{mg} /$ day & $\%$ Contribution & Food groups & $\mathrm{mg} /$ day & $\%$ Contribution & Food groups & $\mathrm{mg} / \mathrm{day}$ & $\%$ Contribution & Food groups & $\mathrm{mg} /$ day & $\%$ Contribution \\
\hline 1 & Salt & $399.3 \pm 41.3$ & $26.8 \pm 1.5$ & Salt & $1016.9 \pm 216.2$ & $28.1 \pm 1.2$ & Salt & $1186.2 \pm 133.7$ & $32.2 \pm 2.3$ & Salt & $1153.5 \pm 104.7$ & $36.5 \pm 1.5$ \\
\hline 2 & Cereals & $253.6 \pm 38.7$ & $13.4 \pm 1.6$ & Cereals & $458.1 \pm 43.3$ & $16.0 \pm 1.2$ & Cereals & $641.7 \pm 117.0$ & $13.6 \pm 1.4$ & Cereals & $448.5 \pm 60.5$ & $12.5 \pm 1.1$ \\
\hline 3 & Dairy & $196.8 \pm 12.3$ & $16.1 \pm 1.3$ & Dairy & $228.8 \pm 20.0$ & $10.2 \pm 0.6$ & Dairy & $287.1 \pm 44.3$ & $8.4 \pm 1.0$ & Red meat & $197.3 \pm 40.6$ & $5.9 \pm 0.9$ \\
\hline 4 & Processed meats & $148.1 \pm 28.1$ & $7.6 \pm 1.2$ & Processed meats & $237.1 \pm 34.7$ & $7.9 \pm 0.8$ & Processed meats & $268.7 \pm 43.5$ & $6.6 \pm 0.9$ & Dairy & $184.0 \pm 16.9$ & $6.7 \pm 0.5$ \\
\hline 5 & Seasonings & $76.6 \pm 20.1$ & $4.4 \pm 1.0$ & Salty snacks & $116.9 \pm 19.3$ & $4.1 \pm 0.4$ & Salty snacks & $172.3 \pm 34.4$ & $4.0 \pm 0.6$ & Processed meats & $178.6 \pm 31.6$ & $4.5 \pm 0.6$ \\
\hline 6 & Eggs & $42.7 \pm 3.7$ & $3.3 \pm 0.3$ & Red meat & $105.4 \pm 17.0$ & $3.6 \pm 0.5$ & Red meat & $159.0 \pm 31.8$ & $4.7 \pm 1.2$ & Seasonings & $125.0 \pm 44.2$ & $3.5 \pm 1.0$ \\
\hline 7 & Salty snacks & $45.5 \pm 15.4$ & $2.3 \pm 0.6$ & Seasonings & $104.1 \pm 30.2$ & $2.7 \pm 0.5$ & Seasonings & $89.02 \pm 19.1$ & $2.5 \pm 0.4$ & Corn tortilla & $95.5 \pm 8.6$ & $4.4 \pm 0.4$ \\
\hline 8 & Red meat & $27.8 \pm 8.4$ & $1.7 \pm 0.4$ & Corn tortilla & $52.2 \pm 4.8$ & $2.9 \pm 0.2$ & Corn tortilla & $87.6 \pm 9.4$ & $3.5 \pm 0.3$ & Eggs & $68.0 \pm 8.9$ & $2.9 \pm 0.4$ \\
\hline 9 & Cereal based sweets & $26.1 \pm 6.1$ & $1.8 \pm 0.4$ & Eggs & $51.6 \pm 4.2$ & $2.9 \pm 0.3$ & Sweet bakery bread & $80.3 \pm 14.6$ & $3.2 \pm 0.6$ & Sweet bakery bread & $63.4 \pm 8.4$ & $2.9 \pm 0.4$ \\
\hline 10 & Non cereal based sweets & $26.5 \pm 4.6$ & $1.8 \pm 0.2$ & R-to-E Cereals & $51.1 \pm 11.0$ & $2.7 \pm 0.4$ & Eggs & $77.7 \pm 9.1$ & $2.7 \pm 0.3$ & Cereals based sweets & $60.3 \pm 18.1$ & $1.9 \pm 0.6$ \\
\hline \multicolumn{13}{|l|}{ Potassium } \\
\hline Ranking & Food groups & $\mathrm{mg} /$ day & $\%$ Contribution & Food groups & $\mathrm{mg} / \mathrm{day}$ & $\%$ Contribution & Food groups & mg/day & $\%$ Contribution & Food groups & $\mathrm{mg} /$ day & $\%$ Contribution \\
\hline 1 & Dairy & $396.7 \pm 32.3$ & $23.7 \pm 1.7$ & Vegetables & $350.3 \pm 42.5$ & $13.5 \pm 0.9$ & Fruits & $414.5 \pm 67.7$ & $11.7 \pm 1.2$ & Vegetables & $701.6 \pm 124.8$ & $17.7 \pm 1.2$ \\
\hline 2 & Fruits & $260.7 \pm 28.5$ & $14.7 \pm 1.2$ & Dairy & $324.2 \pm 29.1$ & $15.6 \pm 0.9$ & Vegetables & $385.7 \pm 46.7$ & $13.2 \pm 1.1$ & Fruits & $467.0 \pm 74.2$ & $12.3 \pm 0.8$ \\
\hline 3 & Vegetables & $168.7 \pm 19.1$ & $9.8 \pm 0.8$ & Fruits & $278.5 \pm 22.3$ & $12.1 \pm 0.8$ & Corn tortilla & $363.3 \pm 38.9$ & $13.8 \pm 0.9$ & Corn tortilla & $401.4 \pm 35.7$ & $13.9 \pm 1.0$ \\
\hline 4 & Yogurt and milk-based drinks & $101.4 \pm 14.5$ & $5.9 \pm 0.8$ & Corn tortilla & $215.9 \pm 19.9$ & $10.8 \pm 0.6$ & Dairy & $360.4 \pm 48.4$ & $11.5 \pm 0.9$ & Legumes & $302.6 \pm 38.1$ & $9.3 \pm 0.9$ \\
\hline 5 & Corn tortilla & $89.3 \pm 9.1$ & $6.4 \pm 0.6$ & Legumes & $149.8 \pm 18.0$ & $6.7 \pm 0.5$ & Legumes & 273.640 .6 & $8.2 \pm 0.8$ & Dairy & $233.2 \pm 26.6$ & $7.9 \pm 0.6$ \\
\hline 6 & Legumes & $81.4 \pm 10.9$ & $5.3 \pm 0.6$ & Root vegetables & $134.2 \pm 34.1$ & $4.2 \pm 0.6$ & Red meat & $161.4 \pm 20.8$ & $5.7 \pm 0.4$ & Root vegetables & $198.6 \pm 47.8$ & $4.5 \pm 0.6$ \\
\hline 7 & SSBs carbonated & $75.6 \pm 11.5$ & $4.8 \pm 0.8$ & Red meat & $101.6 \pm 11.7$ & $4.8 \pm 0.6$ & Cereals & $100.2 \pm 11.3$ & $4.0 \pm 0.4$ & Red meat & $172.0 \pm 24.3$ & $5.9 \pm 0.5$ \\
\hline 8 & Root vegetables & $59.4 \pm 13.7$ & $3.0 \pm 0.5$ & Cereals & $88.2 \pm 6.7$ & $4.5 \pm 0.2$ & Salty snacks & $98.2 \pm 19.0$ & $3.1 \pm 0.5$ & Cereals & $138.9 \pm 27.7$ & $4.2 \pm 0.4$ \\
\hline 9 & Cereals & $55.8 \pm 7.3$ & $4.3 \pm 0.5$ & Yogurt and milk-based drinks & $82.1 \pm 14.9$ & $3.0 \pm 0.4$ & Poultry & $95.4 \pm 23.7$ & $3.4 \pm 0.7$ & Coffee and tea & $134.0 \pm 36.9$ & $3.5 \pm 0.4$ \\
\hline 10 & Poultry & $45.2 \pm 6.2$ & $3.0 \pm 0.4$ & Poultry & $79.7 \pm 11.4$ & $3.3 \pm 0.3$ & Root vegetables & $88.7 \pm 16.01$ & $2.9 \pm 0.4$ & Poultry & $120.8 \pm 21.1$ & $4.2 \pm 0.5$ \\
\hline
\end{tabular}

Salt refers to that reported in the preparations.

SSBs, Sugar-Sweetened Beverages. R-to-E Cereals, Ready to eat cereals. 


\subsection{Contribution of sodium and potassium according to the NOVA classification}

Figure 1 and 2 show the contribution of $\mathrm{Na}$ and $\mathrm{K}$ intake according to the NOVA classification in the Mexican population. Processed and ultra-processed foods and beverages contribute about $49 \%$ of the Na consumed in pre-school children and schoolchildren, $47 \%$ in adolescents, and $39 \%$ in adults (Figure 1 ). Conversely, the consumption of $\mathrm{K}$ is higher in foods and beverages that are unprocessed or minimally processed, since they contribute $68 \%$ in preschool children, $76 \%$ in schoolchildren, $75 \%$ in adolescents, and $83 \%$ in adults (Figure 2). The mean intake and contribution of $\mathrm{Na}$ and $\mathrm{K}$ according to the NOVA classification in the Mexican population are displayed in supplementary table 3.

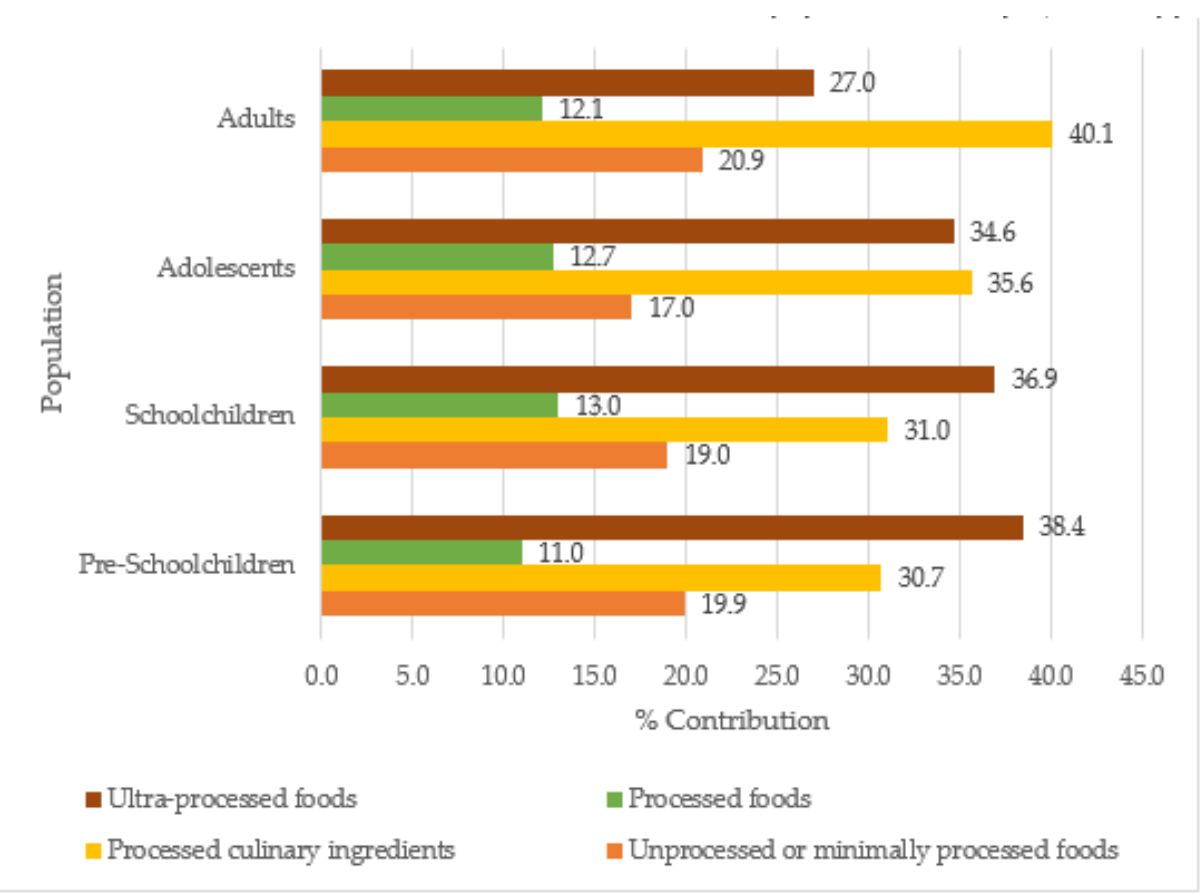

Figure 1. Sodium contribution (percentage) intake by NOVA classification in the Mexican population: ENSANUT 2016. 


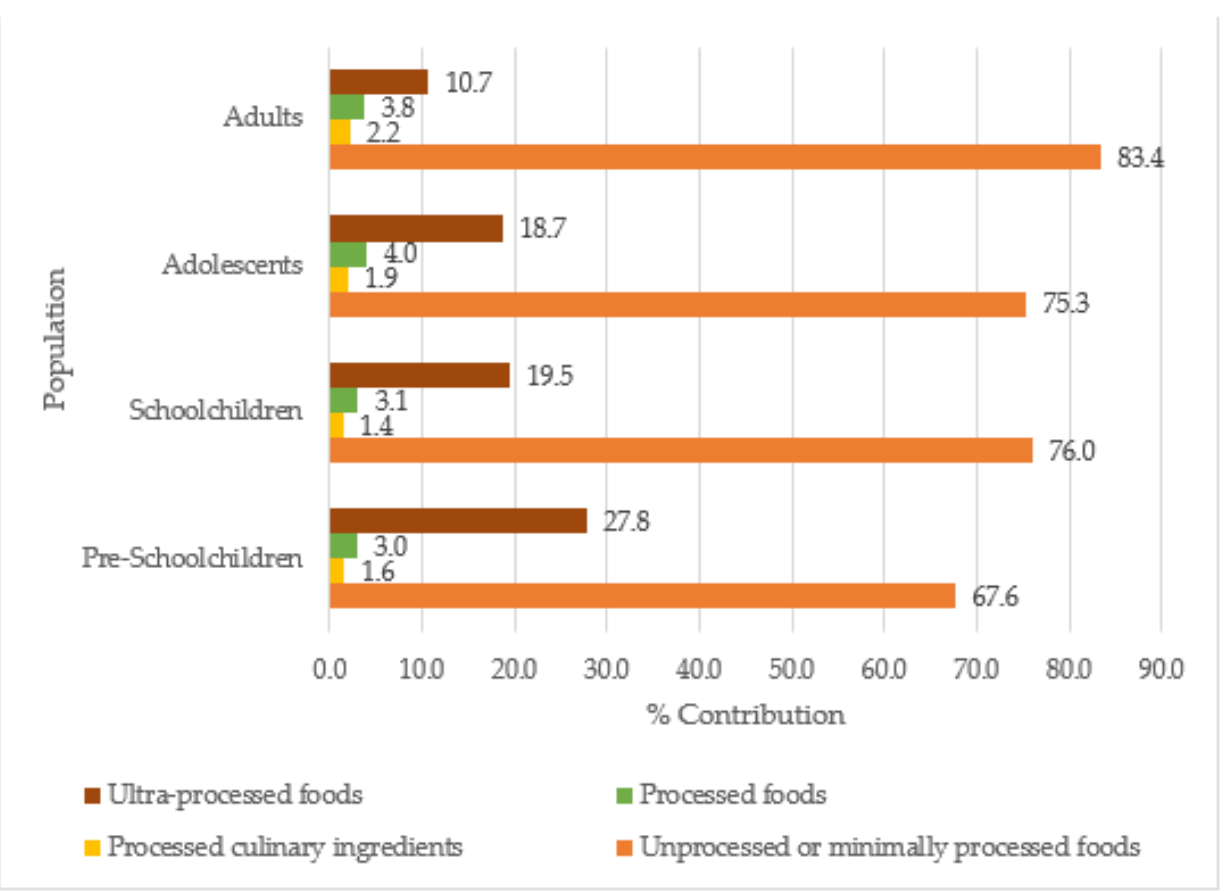

Figure 2. Potassium contribution (percentage) intake by Nova classification in the Mexican population: ENSANUT 2016.

\subsection{Sodium and potassium intake: Health risk}

Table 3 shows the proportion of participants with high $\mathrm{Na}$ and $\mathrm{K}$ consumption, as well as a $\mathrm{Na}: \mathrm{K}$ ratio greater than 1.0. In preschool children, the northern region (55.4\%, C195\%: 38.6-71.0. $\mathrm{p}<0.005$ ) had a higher proportion of children with a Na: K ratio greater than 1 compared to the southern region. Furthermore, it showed a higher proportion of children who had insufficient $K$ intake with low SES (82.0\% CI95\%: 71.2-89.4. $\mathrm{p}<0.005)$, as well as those who were overweight (97.9\% CI95\%: 90.3-99.6). $\mathrm{p}<0.005)$. Among schoolchildren, a higher proportion of children with high Na consumption was observed in urban areas (84.8\% CI95\%: 79.5-89.0. $\mathrm{p}<0.005)$, high SES (87.2\% CI95\%: 79.9-92.1. $\mathrm{p}<0.005)$, as well as those with obesity $(88.0 \%$ CI95\%: 80.0-93.1. $\mathrm{p}$ $<0.005)$. Insufficient $\mathrm{K}$ consumption was observed among children with a normal BMI $(76.5 \%$ 95\% CI: 70.8-81.4. $\mathrm{p}<0.005)$. In addition, those who had a Na: $\mathrm{K}$ ratio greater than 1 were from an urban area $(64.7 \%$. CI95\%: 58.5-70.4. $\mathrm{p}<0.005)$, as well as the northern region $(67.1 \%$. CI95\%: 56.8-76.0. $\mathrm{p}<0.005)$. Among adolescents, a higher proportion of high Na consumption was observed in the northern region (89.5\% CI95\%: 78.1-95.3. $\mathrm{p}<0.005)$, as well as those with overweight (82.4\% CI95\%: 75.8-87.5. P < 0.005) and obesity (86.8\% 95\% CI: 72.7- 94.2. p <0.005). Likewise, those with a higher proportion of insufficient $\mathrm{K}$ consumption were found in the northern region (76.9\% 95\% CI: 52.2-91.0. $\mathrm{p}<0.005)$. Among adults, a higher proportion of people with high SES consumed high amounts of $\mathrm{Na}(70.6 \% 95 \% \mathrm{CI}$ : 60.7-78.9. $\mathrm{p}<0.005)$.

\subsection{Sodium and potassium intake: Cardiovascular health}

Table 4 shows the quartiles of $\mathrm{Na}$ and $\mathrm{K}$ intake in adults according to nutritional status and clinical characteristics. Adults in the fourth quartile of sodium intake (5049.6 $\mathrm{mg} /$ day) had lower serum concentrations of cholesterol (181.4 mg / dL) and HDL-c (35.5 $\mathrm{mg} / \mathrm{dL}$ ) than adults in the first quartile (cholesterol $202.5 \mathrm{mg} / \mathrm{dL}$ and HDL-c $40.8 \mathrm{mg} /$ $\mathrm{dL})(\mathrm{p}<0.005)$. Adults who were in the fourth quartile showed lower levels of HDL-c (34.3 $\mathrm{mg} / \mathrm{dL}$ ) compared to those in the first quartile $(41.6 \mathrm{mg} / \mathrm{dL})(\mathrm{p}<0.005)$. Participants in the third quartile of $\mathrm{K}$ intake (2 $166.5 \mathrm{mg} /$ day) had higher serum concentrations of LDL-c $(123.5 \mathrm{mg} / \mathrm{dL})$ compared to those in the first quartile $(104.9 \mathrm{mg} / \mathrm{dL})(\mathrm{p}<0.005)$. 
Table 3. Percent of population with high sodium and insufficient potassium intake and sodium: potassium ratio in Mexican population. ENSANUT 2016.1,2,3

\begin{tabular}{|c|c|c|c|c|c|c|c|c|c|c|c|c|}
\hline & \multicolumn{3}{|c|}{ Pre-Schoolchildren } & \multicolumn{3}{|c|}{ Schoolchildren } & \multicolumn{3}{|c|}{ Adolescents } & \multicolumn{3}{|c|}{ Adults } \\
\hline & High Na & Insufficient $\mathrm{K}$ & Na:K & High Na & Insufficient $\mathrm{K}$ & Na:K & High Na & Insufficient $K$ & Na:K & High Na & Insufficient $\mathrm{K}$ & Na:K \\
\hline \multicolumn{13}{|c|}{ Total $(\mathrm{n}=4219 ; \mathrm{N}=136,639,494)$} \\
\hline Age & $73.6(66.9,79.4)$ & $73.3(66.2,79.4)$ & $41.5(34.6,48.8)$ & $82.1(78.1,85.6)$ & $67.1(61.5,72.3)$ & $61.1(56.3,65.8)$ & $81.6(76.3,85.9)$ & $58.0(49.1,66.3)$ & $62.5(52.6,71.5)$ & $64.1(57.1,70.5)$ & $65.6(56.7,73.5)$ & $45.7(38.6,53.0)$ \\
\hline \multicolumn{13}{|l|}{ Sex } \\
\hline Women & $74.8(67.0,81.2)$ & $71.9(61.6,80.2)$ & $44.8(35.3,54.7)$ & $80.9(75.4,85.4)$ & $66.8(59.8,73.2)$ & $59.5(53.3,65.5)$ & $79.4(70.5,86.2)$ & $62.1(49.5,73.3)$ & $60.5(44.2,74.7)$ & $60.9(51.0,70.0)$ & $69.7(55.0,81.3)$ & $45.1(35.0,55.6)$ \\
\hline Men & $72.5(61.9,81.1)$ & $74.7(64.5,82.8)$ & $38.4(28.6,49.2)$ & $83.2(77.0,88.0)$ & $67.4(59.0,74.9)$ & $62.6(54.8,69.7)$ & $84.0(76.8,89.3)$ & $53.5(42.0,64.7)$ & $64.8(52.6,75.3)$ & $68.0(58.6,76.1)$ & $60.4(49.5,70.4)$ & $46.4(37.3,55.8)$ \\
\hline \multicolumn{13}{|c|}{ Area of residence } \\
\hline Rural & $71.8(63.3,79.0)$ & $80.5(72.8,86.5)$ & $40.3(31.4,49.9)$ & $75.6(69.9,80.5)$ & $67.1(59.7,73.8)$ & $52.5(46.0,58.9)$ & $79.3(73.5,84.1)$ & $54.0(45.6,62.2)$ & $60.2(53.7,66.4)$ & $65.6(56.1,74.0)$ & $61.5(47.9,73.6)$ & $37.8(27.7,49.1)$ \\
\hline Urban & $74.3(65.49,81.5)$ & $70.7(61.4,78.6)$ & $41.9(33.1,51.3)$ & $84.8(79.5,89.0)$ & $67.1(59.7,73.8)$ & $64.7(58.5,70.4)$ & $82.4(75.5,87.7)$ & $59.3(47.8,69.8)$ & $63.3(50.0,74.8)$ & $63.5(54.5,71.6)$ & $67.1(55.8,76.7)$ & $48.7(39.6,57.8)$ \\
\hline \multicolumn{13}{|l|}{ Region } \\
\hline North & $73.2(58.7,84.1)$ & $70.8(50.9,85.1)$ & $55.4(38.6,71.0)$ & $81.4(71.0,88.6)$ & $75.4(59.3,86.6)$ & $67.1(56.8,76.0)$ & $89.5(78.1,95.3)$ & $76.9(52.2,91.0)$ & $58.2(26.5,84.3)$ & $70.8(53.5,83.6)$ & $52.4(30.3,73.6)$ & $45.8(26.7,66.2)$ \\
\hline Center & $70.4(55.9,81.7)$ & $69.2(55.7,80.0)$ & $39.1(26.9,53.0)$ & $85.0(79.2,89.4)$ & $64.7(55.3,73.0)$ & $65.8(57.1,73.6)$ & $81.2(72.2,87.7)$ & $47.9(36.4,59.5)$ & $67.0(55.2,77.0)$ & $71.3(62.2,78.9)$ & $68.4(55.4,79.0)$ & $47.2(37.0,57.7)$ \\
\hline \multicolumn{13}{|c|}{ Mexico City and } \\
\hline State of Mexico & $78.3(63.1,88.4)$ & $70.2(49.5,85.0)$ & $43.2(26.0,62.1)$ & $88.5(76.1,94.9)$ & $70.5(56.9,81.3)$ & $70.5(59.0,79.8)$ & $72.3(56.8,83.9)$ & $67.9(55.4,78.2)$ & $75.3(57.6,87.3)$ & $58.8(44.7,71.7)$ & $77.0(64.5,86.1)$ & $60.3(46.5,72.6)$ \\
\hline South & $75.4(65.6,83.1)$ & $81.1(71.5,88.0)$ & $35.2(26.1,45.6)$ & $77.2(68.9,83.8)$ & $63.3(53.4,72.2)$ & $49.3(40.8,57.7)$ & $80.9(73.5,86.5)$ & $53.2(41.1,64.9)$ & $54.5(42.7,65.7)$ & $55.3(42.0,67.8)$ & $66.8(52.3,78.6)$ & $38.4(27.3,50.8)$ \\
\hline \multicolumn{13}{|c|}{ Socioeconomic tertile } \\
\hline Low & $70.5(60.5,78.9)$ & $82.0(71.2,89.4)$ & $38.0(28.2,49.0)$ & $75.7(68.8,81.5)$ & $71.2(61.7,79.2)$ & $58.8(50.7,66.5)$ & $75.2(67.1,81.9)$ & $61.7(51.3,71.2)$ & $58.1(49.2,66.6)$ & $49.5(35.6,63.5)$ & $64.4(50.8,76.0)$ & $37.3(26.3,49.9)$ \\
\hline Medium & $71.4(59.0,81.3)$ & $74.3(62.4,83.5)$ & $39.2(27.3,52.5)$ & $81.0(73.9,86.6)$ & $72.0(64.4,78.5)$ & $59.2(51.1,66.9)$ & $83.7(75.7,89.5)$ & $52.2(38.6,65.5)$ & $63.2(48.3,76.0)$ & $64.1(53.0,73.8)$ & $63.4(48.0,76.5)$ & $48.5(35.8,61.4)$ \\
\hline High & $78.7(66.1,87.5)$ & $65.4(51.7,76.9)$ & $47.0(34.2,60.1)$ & $87.2(79.9,92.1)$ & $60.4(49.9,70.0)$ & $64.2(55.6,72.0)$ & $83.1(73.0,89.9)$ & $60.6(45.2,74.1)$ & $64.1(44.4,80.0)$ & $70.6(60.7,78.9)$ & $67.2(52.0,79.5)$ & $47.9(36.8,59.2)$ \\
\hline \multicolumn{13}{|l|}{ BMI a $\left(\mathrm{kg} / \mathrm{m}^{2}\right)$} \\
\hline Normal & $72.3(65.1,78.5)$ & $74.9(67.0,81.4)$ & $41.8(34.3,49.7)$ & $78.5(72.8,83.3)$ & $76.5(70.8,81.4)$ & $59.1(53.2,64.8)$ & $68.1(61.0,74.5)$ & $69.0(62.8,74.5)$ & $60.3(52.3,67.8)$ & $60.8(47.6,72.6)$ & $70.8(57.1,81.6)$ & $45.4(33.7,57.8)$ \\
\hline Overweight & $71.2(29.6,93.6)$ & $97.9(90.3,99.6)$ & $41.6(14.0,75.7)$ & $84.7(75.4,90.9)$ & $60.3(48.7,70.8)$ & $60.2(48.4,70.9)$ & $82.4(75.8,87.5)$ & $75.7(65.5,83.6)$ & $70.1(60.6,78.1)$ & $61.7(51.5,71.0)$ & $73.0(59.7,83.1)$ & $47.9(37.9,58.1)$ \\
\hline Obesity & 100 & $40.3(11.0,78.8)$ & $68.4(28.8,92.1)$ & $88.0(80.0,93.1)$ & $66.6(49.4,80.2)$ & $61.5(48.1,73.3)$ & $86.8(72.7,94.2)$ & $81.5(58.1,93.3)$ & $50.6(19.4,81.3)$ & $68.0(56.7,77.4)$ & $56.4(41.7,70.0)$ & $44.0(32.0,56.8)$ \\
\hline
\end{tabular}

Bold numbers means statistically significant difference vs reference category $(\mathrm{p}<0.05)$, using logistic regression models.

The reference category is the first row of each variable; except for the first variable (age), in wich is the first column.

Data represents percent's and confidence intervals $(95 \%)$, also was adjusted for the survey design.

* Self-report of previous medical diagnosis of the described diseases.

a Body mass index (BMI): $<25 \mathrm{~kg} / \mathrm{m} 2$ (normal); $25-29.9 \mathrm{~kg} / \mathrm{m} 2$ (overweight); $\geq 30 \mathrm{~kg} / \mathrm{m} 2$ (obesity). For those under 19 years of age, the BMI for age was used according to the WHO 


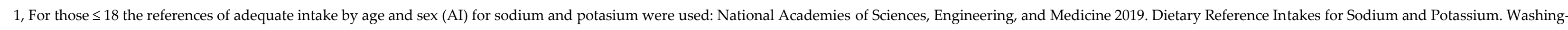

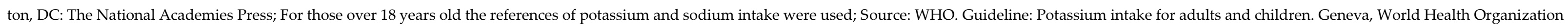
(WHO), 2012 and WHO. Guideline: Sodium intake for adults and children. Geneva, World Health Organization (WHO), 2012.

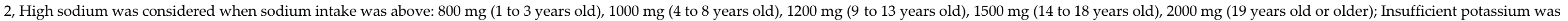

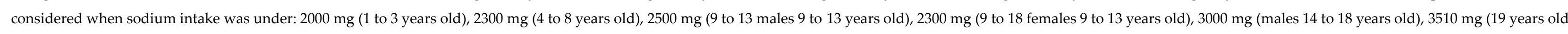
or older).

3, Na:K $>1.0$

$\mathrm{Na}$, Sodium; K, Potassium.

Table 4. Nutritional status and clinical characteristics according to quartiles of sodium and potassium intake in adults: ENSANUT 2016

\begin{tabular}{|c|c|c|c|c|c|c|c|c|c|c|}
\hline \multirow{2}{*}{$\begin{array}{l}\text { Sodium Intake Quartiles (mg/day) } \\
\text { Quartile, Mean, 95\% CI }\end{array}$} & \multicolumn{2}{|r|}{ First } & \multicolumn{2}{|c|}{ Second } & \multicolumn{2}{|r|}{ Third } & \multicolumn{2}{|r|}{ Fourth } & \multirow{2}{*}{ p } & \multirow{2}{*}{$\frac{n}{1,356}$} \\
\hline & 801.8 & $(761.9,841.7)$ & 1578.93 & $(1517.6,1649.2)$ & 2438.4 & $(2381.6,2494.9)$ & 5049.6 & $(4579.4,5519.8)$ & & \\
\hline BMI $\left(\mathrm{kg} / \mathrm{m}^{2}\right)$, mean $(95 \% \mathrm{CI})$ & 28.7 & $(27.2,30.2)$ & 28.5 & $(27.2,29.8)$ & 28.7 & $(27.0,30.3)$ & 28.2 & $(27.1,29.4)$ & 0.966 & 1,294 \\
\hline Waist circumference $(\mathrm{cm})$. Women, mean $(95 \% \mathrm{CI})$ & 96.4 & $(91.4,101.3)$ & 93.5 & $(88.9,98.2)$ & 94.2 & $(90.2,98.2)$ & 94.1 & $(90.8,97.4)$ & 0.853 & 554 \\
\hline Men, mean $(95 \% \mathrm{CI})$ & 98.562 & $(89.8,107.3)$ & 95.0 & $(90.9,99.1)$ & 98.1 & $(93.8,102.5)$ & 97.3753 & $(92.0,102.8)$ & 0.749 & 356 \\
\hline SBP (mm Hg), mean $(95 \% \mathrm{CI})$ & 123.2 & $(119.7,126.8)$ & 128.3 & $(119.6,136.9)$ & 120.5 & $(117.1,123.9)$ & 122.1 & $(117.2,127.0)$ & 0.373 & 901 \\
\hline DBP (mm Hg), mean $(95 \% \mathrm{CI})$ & 73.7 & $(71.3,76.2)$ & 76.4 & $(73.1,79.7)$ & 73.4 & $(70.9,75.8)$ & 72.1 & $(69.6,74.6)$ & 0.259 & 901 \\
\hline eGFR $\left(\mathrm{mL} / \mathrm{min} / 1.73 \mathrm{~m}^{2}\right)$, mean $(95 \% \mathrm{CI})$ & 116.6 & $(110.6,122.5)$ & 113.7 & $(107.4,120.1)$ & 123.3 & $(108.2,138.4)$ & 112.4 & $(108.3,116.5)$ & 0.486 & 922 \\
\hline Glucose $(\mathrm{mg} / \mathrm{dL})$, mean $(95 \% \mathrm{CI}) \mathrm{a}$ & 107.4 & $(101.4,113.4)$ & 115.8 & $(96.0,135.5)$ & 109.9 & $(98.0,121.7)$ & 101.0 & $(95.9,106.0)$ & 0.185 & 922 \\
\hline Cholesterol (mg/dL), mean $(95 \% \mathrm{CI}) \mathrm{a}$ & 202.5 & $(189.0,216.0)$ & 193.5 & $(178.4,208.6)$ & 184.4 & $(172.8,196.1)$ & 181.4 & $(173.6,189.1)$ & 0.058 & 922 \\
\hline HDL-c (mg/dL), mean (95\% CI)a & 40.8 & $(38.1,43.6)$ & 35.7 & $(31.639 .8)$ & 38.9 & $(35.2,42.6)$ & 35.5 & $(33.2,37.8)$ & 0.026 & 922 \\
\hline LDL-c $(\mathrm{mg} / \mathrm{dL})$, mean $(95 \% \mathrm{CI}) \mathrm{a}$ & 123.6 & $(110.1,137)$ & 115.3 & $(108.3,122.3)$ & 111.9 & $(102.3,121.4)$ & 106.6 & $(98.8,114.3)$ & 0.156 & 865 \\
\hline TG $(\mathrm{mg} / \mathrm{dL})$, mean $(95 \% \mathrm{CI}) \mathrm{a}$ & 197.8 & $(176.3,219.3)$ & 361.5 & $(79.9,643.1)$ & 218.8 & $(153.4,284.3)$ & 220.5 & $(170.3,270.6)$ & 0.547 & 922 \\
\hline \multicolumn{11}{|l|}{ Diabetes $^{a}(\%)$} \\
\hline Prediabetes & 24.6 & $(17.4,33.6)$ & 27.79 & $(15.0,45.6)$ & 32.92 & $(21.7,46.6)$ & 28.46 & $(16.5,44.6)$ & 0.548 & 926 \\
\hline Previous diagnosis & 12.31 & $(7.9,18.8)$ & 8.107 & $(4.6,13.8)$ & 7.305 & $(4.2,12.4)$ & 6.175 & $(3.3,11.2)$ & & \\
\hline Survey finding & 9.9 & $(3.7,24.2)$ & 15.3 & $(3.7,46.4)$ & 9.1 & $(2.4,28.6)$ & 3.7 & $(1.3,9.9)$ & & \\
\hline
\end{tabular}


High blood pressure ${ }^{\text {(\%) }}$

\begin{tabular}{|c|c|c|c|c|c|c|c|c|c|c|}
\hline Elevated & 11.5 & $(6.7,19.2)$ & 11.8 & $(4.9,25.7)$ & 18.3 & $(8.6,34.9)$ & 15.3 & $(8.4,26.4)$ & 0.213 & 901 \\
\hline Stage 1 & 23.7 & $(13.3,38.6)$ & 20.8 & $(9.6,39.4)$ & 21.7 & $(11.1,38.0)$ & 9.8 & $(5.5,17.0)$ & & \\
\hline Stage 2 & 7.9 & $(4.5,13.5)$ & 25.6 & $(10.4,50.6)$ & 8.4 & $(4.6,15.0)$ & 11.4 & $(4.4,26.5)$ & & \\
\hline Previous diagnosis & 13.2 & $(8.7,19.6)$ & 9.7 & $(5.6,16.3)$ & 9.3 & $(4.5,18.3)$ & 16.7 & $(8.0,31.6)$ & & \\
\hline Coronary Heart Disease (\%) & 0.7 & $(0.1,3.4)$ & 1.5 & $(0.6,4.2)$ & 1.9 & $(0.6,5.7)$ & 4.1 & $(0.7,21.7)$ & 0.385 & 926 \\
\hline Cerebro-vascular Disease (\%) & 0.0 & & 0.5 & $(0.1,3.3)$ & 0.1 & $(0.0,1.1)$ & 0.9 & $(0.1,6.0)$ & 0.580 & 916 \\
\hline \multicolumn{11}{|l|}{ Smoking (\%) } \\
\hline Never & 43.2 & $(32.0,55.1)$ & 65.8 & $(51.5,77.8)$ & 54.9 & $(40.8,68.2)$ & 31.8 & $(21.3,44.5)$ & 0.002 & 926 \\
\hline Current smoker & 20.1 & $(11.4,33.1)$ & 6.4 & $(3.6,11.1)$ & 13.7 & $(7.0,25.2)$ & 30.9 & $(18.4,46.9)$ & & \\
\hline Ex-smoker & 36.7 & $(26.2,48.7)$ & 27.8 & $(17.4,41.3)$ & 31.4 & $(20.2,45.3)$ & 37.3 & $(24.8,51.8)$ & & \\
\hline Potasium Intake Quartiles (mg/day) & \multicolumn{2}{|r|}{ First } & \multicolumn{2}{|c|}{ Second } & \multicolumn{2}{|r|}{ Third } & \multicolumn{2}{|r|}{ Fourth } & $\mathbf{p}$ & $n$ \\
\hline Quartile, Mean, 95\% CI & 965.4 & $(921.1,1009.7)$ & 1552.2 & $(1510.6,1593.7)$ & 2210.9 & $(2166.5,2255.5)$ & 5039.5 & $(4338.9,5740.1)$ & - & 1,356 \\
\hline BMI $\left(\mathrm{kg} / \mathrm{m}^{2}\right)$, mean $(95 \% \mathrm{CI})$ & 28.3 & $(27.1,29.5)$ & 27.4 & $(26.4,28.5)$ & 29.4 & $(28.2,30.6)$ & 28.6 & $(27.3,29.9)$ & 0.096 & 1,294 \\
\hline Waist circumference $(\mathrm{cm})$, mujeres, mean $(95 \% \mathrm{CI})$ & 98.2 & $(93.5,102.9)$ & 93.6 & $(89.4,97.7)$ & 96.6 & $(93.0,100.3)$ & 92.1 & $(88.9,95.4)$ & 0.143 & 554 \\
\hline Men, mean $(95 \% \mathrm{CI})$ & 91.4 & $(87.5,95.3)$ & 95.7 & $(91.3,100.0)$ & 98.4 & $(94.8,102.1)$ & 98.2 & $(93.4,103.1)$ & 0.056 & 356 \\
\hline SBP $(\mathrm{mm} \mathrm{Hg})$, mean $(95 \% \mathrm{CI})$ & 122.0 & $(117.8,126.2)$ & 122.4 & $(116.8,127.9)$ & 122.3 & $(119.6,125.0)$ & 123.7 & $(118.6,128.8)$ & 0.959 & 901 \\
\hline DBP $(\mathrm{mm} \mathrm{Hg})$, mean $(95 \% \mathrm{CI})$ & 73.9 & $(70.6,77.2)$ & 74.5 & $(71.7,77.2)$ & 74.4 & $(72.1,76.7)$ & 72.8 & $(70.5,75.2)$ & 0.758 & 901 \\
\hline eGFR $\left(\mathrm{mL} / \mathrm{min} / 1.73 \mathrm{~m}^{2}\right)$, mean $(95 \% \mathrm{CI})$ & 115.2 & $(112.0,118.4)$ & 117.6 & $(110.4,124.7)$ & 118.0 & $(113.1,122.8)$ & 115.3 & $(107.2,123.4)$ & 0.819 & 922 \\
\hline Glucose $(\mathrm{mg} / \mathrm{dL})$, mean $(95 \% \mathrm{CI})^{\mathrm{a}}$ & 118.0 & $(98.0,138.0)$ & 102.0 & $(97.1,106.9)$ & 105.9 & $(99.2,112.6)$ & 106.7 & $(97.5,115.9)$ & 0.289 & 922 \\
\hline Cholesterol $(\mathrm{mg} / \mathrm{dL})$, mean $(95 \% \mathrm{CI})^{\mathrm{a}}$ & 181.8 & $(172.1,191.6)$ & 187.9 & $(176.9,198.8)$ & 198.7 & $(187.8,209.5)$ & 184.1 & $(174.7,193.6)$ & 0.112 & 922 \\
\hline HDL-c (mg/dL), mean $(95 \% \mathrm{CI})^{\text {a }}$ & 41.6 & $(39.3,43.9)$ & 39.9 & $(33.3,46.5)$ & 40.1 & $(37.7,42.4)$ & 34.3 & $(32.4,36.1)$ & 0.000 & 922 \\
\hline LDL-c $(\mathrm{mg} / \mathrm{dL})$, mean $(95 \% \mathrm{CI})^{a}$ & 104.9 & $(95.7,114.1)$ & 112.7 & $(104.2,121.2)$ & 123.5 & $(113.5,133.5)$ & 108.7 & $(101.4,115.9)$ & 0.036 & 865 \\
\hline TG $(\mathrm{mg} / \mathrm{dL})$, mean $(95 \% \mathrm{CI})^{a}$ & 225.6 & $(145.9,305.2)$ & 224.9 & $(113.0,336.9)$ & 235.3 & $(160.9,309.8)$ & 258.7 & $(145.3,372.1)$ & 0.969 & 922 \\
\hline \multicolumn{11}{|l|}{ Diabetesa $(\%)$} \\
\hline Prediabetes & 24.7 & $(14.8,38.3)$ & 29.3 & $(16.8,46.0)$ & 24.8 & $(14.9,38.4)$ & 31.5 & $(20.4,45.2)$ & 0.505 & 926 \\
\hline
\end{tabular}


Previous diagnosis

Survey finding

High blood pressure $(\%)$

\begin{tabular}{|c|c|c|c|c|c|c|c|c|c|c|}
\hline Elevated & 10.1 & $(4.9,19.6)$ & 9.4 & $(5.0,16.8)$ & 20.3 & $(10.4,35.8)$ & 15.9 & $(8.7,27.5)$ & 0.754 & 901 \\
\hline Stage 1 & 24.5 & $(9.3,50.6)$ & 22.9 & $(11.8,39.8)$ & 19.3 & $(10.6,32.4)$ & 12.7 & $(7.6,20.6)$ & & \\
\hline Stage 2 & 8.9 & $(4.2,18.1)$ & 12.7 & $(5.1,28.2)$ & 11.0 & $(5.9,19.5)$ & 14.8 & $(6.5,30.1)$ & & \\
\hline Previous diagnosis & 9.1 & $(5.1,15.6)$ & 13.7 & $(8.1,22.3)$ & 13.3 & $(7.9,21.6)$ & 13.2 & $(6.3,25.6)$ & & \\
\hline Coronary Heart Disease (\%) & 1.0 & $(0.3,3.5)$ & 0.7 & $(0.1,4.6)$ & 3.2 & $(1.2,7.9)$ & 3.2 & $(0.6,16.8)$ & 0.496 & 926 \\
\hline Cerebro-vascular Disease (\%) & 0.7 & $(0.1,5.3)$ & 0.0 & 0 & 0.2 & $(0.0,1.6)$ & 0.7 & $(0.1,4.6)$ & 0.699 & 916 \\
\hline \multicolumn{11}{|l|}{ Smoking (\%) } \\
\hline Never & 58.2 & $(42.3,72.5)$ & 50.8 & $(36.7,64.7)$ & 45.4 & $(33.7,57.7)$ & 42.5 & $(30.7,55.2)$ & 0.691 & 926 \\
\hline Current smoker & 17.8 & $(8.9,32.2)$ & 20.2 & $(10.8,34.5)$ & 22.4 & $(12.9,36.0)$ & 19.6 & $(10.3,34.0)$ & & \\
\hline Ex-smoker & 24.1 & $(15.5,35.4)$ & 29.1 & $(19.6,40.8)$ & 32.2 & $(22.1,44.2)$ & 37.9 & $(26.7,50.7)$ & & \\
\hline
\end{tabular}

${ }^{*}$ Data adjusted for the survey design.

a Body mass index (BMI): $<25 \mathrm{~kg} / \mathrm{m}^{2}$ (normal); $25-29.9 \mathrm{~kg} / \mathrm{m}^{2}$ (overweight); $\geq 30 \mathrm{~kg} / \mathrm{m}^{2}$ (obesity)

b Blood pressure (mm Hg): normal (<120/80); elevated (systolic between 120-129 and diastolic <80); stage 1 (systolic between 130-139 or diastolic between 80-89); stage 2 (systolic at least 140 or diastolic at least 90).

c Diabetes classification: prediabetes (fasting glucose $\geq 100 \mathrm{y}<126 \mathrm{mg} / \mathrm{dL}$ or HbA1c $\geq 5.7$ and $<6.5 \%$ ); survey finding (fasting glucose $\geq 126 \mathrm{mg} / \mathrm{dL}$ or $\mathrm{HbA} 1 \mathrm{c} \geq 6.5 \%$ ).

d High total cholesterol levels: $\geq 200 \mathrm{mg} / \mathrm{dL}$

e High LDL-c levels: $\geq 100 \mathrm{mg} / \mathrm{dL}$.

f Low HDL-c levels (hypoalphalipoproteinemia): $<40 \mathrm{mg} / \mathrm{dL}$.

g High triglycerides levels: $\geq 150 \mathrm{mg} / \mathrm{dL}$.

Bold numbers indicate statistically significant difference between first quartile and other quartiles $(p<0.05)$. 


\section{Discussion}


Our results showed a consumption of Na $1512 \mathrm{mg} /$ day and K $1616 \mathrm{mg}$ /day for preschoolchildren. In Mexicans the amount of $\mathrm{Na}$ is high for the age, however, the Japanese population (2 $300 \mathrm{mg}$ ) [51], Poland (1 $220 \mathrm{mg}$ ) [52] and Australia (3 $400 \mathrm{mg}$ ) [53] consume more Na. For K consumption, it is higher in Japan (1 $700 \mathrm{mg}$ ) [51] and lower in Poland (947 mg) [52] and Australia (1 $119 \mathrm{mg}$ ) [53]. This may be due to cultural differences between countries. Also, the consumption of processed foods may be greater in developing countries. Mexico exceeds amounts recommended by the WHO and the IOM probably due to poor diet quality [54].

In schoolchildren, Na consumption exceeds the WHO recommendation, while K consumption was below the recommended level; the $\mathrm{Na} / \mathrm{K}$ ratio was 1.4 (95\% CI 1.1, 1.7). These results coincide with those obtained in Indonesian children between 9 and 12 years, who had a high Na consumption ( $>2300 \mathrm{mg} /$ day) and a low K consumption (<2 $500 \mathrm{mg} /$ day) [55]. On the other hand, in Spanish children between 9 and 13 years old, Na consumption was close to 2 $500 \mathrm{mg}$ /day, while K consumption was $2800 \mathrm{mg}$ /day [56]. Guatemalan children (6-11 y) reported a low consumption of $\mathrm{Na}(831 \mathrm{mg} /$ day), as well as a low consumption of K (1 364 $\mathrm{mg} /$ day) [57].

The main food groups that contribute to Na consumption in this population group are salt, cereals, dairy products, processed meats, salty snacks, red meats, and seasonings. Food groups such as dairy, vegetables, fruits, as well as corn tortillas and root vegetables contribute the most $\mathrm{Na}$ to the diet. These results are consistent with those obtained by Grimes et al, since they showed that in Australian children between 4 and 12 years, the main food groups that contributed to a high $\mathrm{Na}$ intake in the diet were cereals, as well as meat, poultry, condiments or seasonings, and flavoring sauces. While the consumption of $K$, this population showed that milk products and dishes, as well as vegetables, fruits, meats and cereals contribute most of the consumption of this nutrient [58]. On the other hand, Cuadrado et al., showed that the main food sources that contributed Na to the diet in Spanish children between 7 and 11 years old were meats and meat products, cereals, grains and legumes, as well as pre-cooked and ready-to-eat meals [48]. This may also be due to the fact that non-basic foods that are high in fat and sugar, animal products, and milk and dairy derivatives were found to contribute $22 \%$ to total dietary energy in schoolchildren [42].

In adolescents, the mean dietary $\mathrm{Na}$ intake was higher and the mean dietary K intake was below the levels recommended by international agencies. These results were consistent with international studies; for example, Portuguese adolescents showed a high mean dietary Na intake (3 $500 \mathrm{mg} /$ day) while the mean dietary K intake was low (2 $150 \mathrm{mg} /$ day) [59]. Furthermore, adolescents in Morocco reported consuming more than $2134 \mathrm{mg} /$ day [57], while adolescents in China reported consuming a median consumption of dietary Na of $4300 \mathrm{mg} /$ day while consuming $1600 \mathrm{mg}$ /day of dietary K [60]. In this population group, the main sources of foods that contributed Na were salt, cereals, dairy products, processed meats, salty snacks and red meat. The main food sources that contributed a high $\mathrm{K}$ intake were fruits, vegetables, corn tortillas, dairy, legumes, and red meat [61]. These results were consistent with that of American adolescents since the main food sources that contributed to high Na intake were mixed dishes - pizza, mixed-Mexican dishes, as well as mixed avocado-sandwiches, as well as breads, rolls and tortillas [61]. On the other hand, the main food sources that contributed to $\mathrm{K}$ consumption were milk, white potatoes, fruits, $100 \%$ juices, poultry and mixed-Mexican dishes [62]. This may be because this population group is the one that consumes the least fruits and vegetables compared to adults and those under 12 years of age. In addition, adolescents have been identified to have a Western diet pattern, which is characterized by high processed food and salt intake [42].

Mexican adults have a high Na intake (3 $132 \mathrm{mg}$ / day), as well as a low K intake (3,400 $\mathrm{mg} /$ day). The previous results were consistent with previous studies obtained from the SALMEX cohort in Mexico City [10]. This study showed that the estimated Na intake was high (2 $600 \mathrm{mg} /$ day), while the (urinary) K intake was low (1982 mg/day) [10]. A study carried out in China showed that Na consumption in the adult population was above $4100 \mathrm{mg} /$ day, while K consumption was between 1500 and $1600 \mathrm{mg} /$ day [63]. A study carried out with Australian adults showed that the median K intake was high, since it was above $3000 \mathrm{mg} /$ day [64]. Another study carried out with American adults showed that the mean population consumption was close to $3500 \mathrm{mg} /$ day, while the mean $\mathrm{K}$ consumption was close to 2800 $\mathrm{mg}$ /day [65]. Our results did not show a high proportion between Na: K; however, other countries have shown that these proportions are above two [63,64], which was related to diastolic and systolic pressure. Mexican adults have shown to have the highest potassium consumption in the population. However, this is not sufficient to comply with the WHO recommendations. Potassium consumption is higher than in other countries, probably because consumption of non-basic foods (14\%) in the adult diet is lower than that of minors [42]. 
Our results showed that the food groups that most contribute to Na consumption are salt, cereals, red meat, dairy, processed meats, as well as seasonings, while the food groups that contribute the most to K consumption are vegetables, fruits, corn tortillas, legumes, dairy, as well as root vegetables. These results are slightly consistent with those obtained in a subsample of the SALMEX cohort [66]. For instance, this study showed that processed meats, savory breads, sweet bakery goods, natural cheeses, as well as tacos and breakfast cereals, were the main sources of $\mathrm{Na}$ in the diet [66]. This may be due to the fact that our results have national coverage and there is a greater variety of food consumption in different regions. A study conducted with Chinese adults showed that the main source of Na distribution was salt $(69 \%)$, as well as soy sauce (8\%) and processed food (6\%) [67]. However, the Mexican diet is different from this population; it has higher mortality rates attributed to a high Na intake compared to Mexico [44]. In addition to the above, our results are consistent with a study conducted with Australian adults, in which the main sources of K consumption were vegetables, meat, poultry, fruits, and milk products [64].

Finally, the mealtimes that contributed the most to higher consumption of $\mathrm{Na}$ and $\mathrm{K}$ was the fourth mealtime and breakfast (first mealtime). These results contradict the results obtained from a study with the Japanese population, since dinner was the main mealtime that contributed most. This may be since the meal times in the first years of life are prepared at home and heavy meals are usually eat at these times. The main food groups that contributed $\mathrm{Na}$ to the diet were cereals, dairy products and processed meats. These data were consistent with a study from Australian, since their main source of Na was cereals and cereal products, milk products and meat-poultry dishes [53]. On the other hand, the main sources of K consumption in our study were dairy products, fruits and vegetables, as well as yogurt and milk based beverages. These were also consistent with Australia: milk products, fruits products/ dishes, vegetables products/ dishes and cereals [53]. These foods also contributed the most $\mathrm{K}$ to the diet in the Polish population [53]. This may be because the first stages of consumption (in early childhood) involve dairy products and also, according to the complementary feeding scheme, some of the first foods consumed are cereals, vegetables and fruits [68].

The main strengths of this study are that it is based on a representative sample, it includes all age groups nationwide, and is the first to identify the main dietary sources of $\mathrm{Na}$ and $\mathrm{K}$, meal times, and mean intakes. The detailed dietary intake data were collected at the brand level for each food consumed and Na values were updated with analytical data on Mexican foods. In addition, we measured cardio metabolic risk biomarkers with a high precision. The main limitation of this study is that the instrument was not designed for the main objective of this study. Therefore, sodium intake may be underestimated. However, the population-based information generated in this investigation is essential to help design, evaluate, and reformulate strategies to reduce $\mathrm{Na}$ intake and increase $\mathrm{K}$ intake in Mexico. On the other hand, $\mathrm{Na}$ intake is a combined sum of Na present in natural food (approximately 10\%), Na added by the consumer when cooking and at the table (approximately 36\%) and that present in processed food as added during the manufacturing process (approximately 54\%). Hence, dietary assessments would tend to grossly underestimate total salt intake since this study did not consider some of the main sources of sodium added at the table.

\section{Conclusions}

Our results show that a high proportion of the Mexican population, including most age and gender groups, have high $\mathrm{Na}$ and low $\mathrm{K}$ intakes, as well as an inadequate Na:K ratio. These findings are consistent with studies carried out worldwide showing that Na consumption is high in accordance with international recommendations, while $\mathrm{K}$ consumption is low.

In Mexico, it would be important to promote a diet with foods rich in $\mathrm{K}$ such as fruits, vegetables, legumes as well as milk from an early age. Although these foods are the main sources of $\mathrm{K}$ intake in this population, their current consumption seems insufficient to provide enough $\mathrm{K}$ in the diet. There is a relationship between higher sodium consumption and cholesterol, HDL and LDL levels, compared to people who consumed less sodium. In addition, the results of this article highlight the importance of implementing reformulation strategies in processed and ultra-processed foods and beverages because they contribute most of the sodium consumed. If this trend continues, the probability of having an unhealthy $\mathrm{Na}: \mathrm{K}$ ratio will increase, along with cardiovascular risk.

Supplementary Materials: Table S1: Description of the food groups used in the analysis of the food and beverage groups contributing to sodium and potassium intake- Table S2: Sodium and potassium consumption and contribution by meal times and places of consumption in Mexican population: ENSANUT 2016. Table S3: Supplementary Table 3 Mean and contribution of sodium and potassium intake by Nova classification in Mexican population: ENSANUT 2016. 
Author Contributions: Conceptualization, J.V.M., M.A.C.A and I.C.N.; methodology, J.V.M., and I.C.N.; formal analysis, M.A.C.A, J.V.M., and J.A.M.P.; writing-original draft preparation, X.X.; writing-review and editing, J.V.M., and I.C.N.; funding acquisition, I.C.N.; Critical revision of the drafted manuscript, C.N., S.B., M.F.A. and S. R. All authors have read and agreed to the published version of the manuscript.

Funding: This research was funded by Bloomberg Philanthropies.

Institutional Review Board Statement: All participants signed the informed consent approved by the Institutional Review Board of the National Institute of Public Health in Mexico. This study was a secondary data analysis; Ethics and Research Commissions of the MNIPH with the Commission number 1401, Bioethics registration 17 CEI00120130424, and COFEPRIS registration CEI 1700736 approved the original protocol.

Informed Consent Statement: Participants signed the informed consent approved by the Institutional Review Board of the National Institute of Public Health in Mexico.

Data Availability Statement: The data that support the findings of this study are available from the first author upon reasonable request.

Acknowledgments: Not applicable.

Conflicts of Interest: The authors declare no conflict of interest.

\section{References}

1.

IOM (Institute of Medicine). Dietary Reference Intakes for water, potassium, sodium, chloride and sulfate; 2008; ISBN 0309091586.

Pirahanchi, Y.; Jessu, R.; Aeddula, N.R. Physiology, Sodium Potassium Pump. In; Treasure Island (FL), 2021.

Grillo, A.; Salvi, L.; Coruzzi, P.; Salvi, P.; Parati, G. Sodium intake and hypertension. Nutrients 2019, 11, 1-16, doi:10.3390/nu11091970.

Smyth, A.; O’Donnell, M.J.; Yusuf, S.; Clase, C.M.; Teo, K.K.; Canavan, M.; Reddan, D.N.; Mann, J.F.E. Sodium intake and renal outcomes: a systematic review. Am. J. Hypertens. 2014, 27, 1277-1284, doi:10.1093/ajh/hpt294.

Jr, R.C.M.; Schmidlin, O.; Frassetto, L.A.; Sebastian, A.; Morris, R.C.; Schmidlin, O.; Frassetto, L.A.; Sebastian, A. Relationship and Interaction between Sodium and Potassium Relationship and Interaction between Sodium and. J. Am. Coll. Nutr. 2013, 25:sup3, 2, 37-41, doi:10.1080/07315724.2006.10719576.

Newberry, S.J.; Chung, M.; Anderson, C.A.M.; Chen, C.; Fu, Z.; Tang, A.; Zhao, N.; Booth, M.; Marks, J.; Hollands, S.; et al. Sodium and Potassium Intake: Effects on Chronic Disease Outcomes and Risks [Internet]; Rockville (MD), 2018;

National Academies of Sciences Engineering and Medicine Dietary Reference Intakes for Sodium and Potassium; The National AcademiesThe National Academies Press, Ed.; Washington (DC), 2019; ISBN 978-0-309-48834-1.

OMS. Organización Mundial de la Salud Ingesta de sodio en adultos y niños; Geneva Switzerland, 2013;

Mozaffarian, D.; Fahimi, S.; Singh, G.M.; Micha, R.; Khatibzadeh, S.; Engell, R.E.; Lim, S.; Danaei, G.; Ezzati, M.; Powles, J. Global Sodium Consumption and Death from Cardiovascular Causes. N. Engl. J. Med. 2014, 371, 624-634, doi:10.1056/NEJMoa1304127. Vega-Vega, O.; Fonseca-Correa, J.I.; Mendoza-De la Garza, A.; Rincón-Pedrero, R.; Espinosa-Cuevas, A.; Baeza-Arias, Y.; Dary, O.; Herrero-Bervera, B.; Nieves-Anaya, I.; Correa-Rotter, R. Contemporary dietary intake: Too much sodium, not enough potassium, yet sufficient iodine: The SALMEX cohort results. Nutrients 2018, 10, 1-11, doi:10.3390/nu10070816.

Arcand, J.; Blanco-Metzler, A.; Aguilar, K.B.; L'abbe, M.R.; Legetic, B. Sodium levels in packaged foods sold in 14 latin american and Caribbean countries: A food label analysis. Nutrients 2018, 11, 1-8, doi:10.3390/nu11020369.

Organización Mundial de la Salud Alimentos y bebidas ultraprocesados en América Latina: tendencias, efecto sobre la obesidad e implicaciones para las políticas públicas; 2015; ISBN 9789275718643.

Centers for Disease Control and Prevention, C. Top 10 Sources of Sodium Available online: https://www.cdc.gov/salt/sources.htm (accessed on May 17, 2021). Marrón-Ponce, J.A.; Tolentino-Mayo, L.; Hernández-F, M.; Batis, C. Trends in ultra-processed food purchases from 1984 to 2016 in Mexican households. Nutrients 2019, 11, 1-15, doi:10.3390/nu11010045.

Graudal, N.A.; Hubeck-Graudal, T.; Jurgens, G. Effects of low sodium diet versus high sodium diet on blood pressure, renin, aldosterone, catecholamines, cholesterol, and triglyceride. Cochrane Database Syst. Rev. 2017, 2017, doi:10.1002/14651858.CD004022.pub4.

Vallejo, M.; Col, E.; Madero, M.; V, O.I. Assessment of Sodium and Potassium Intake by 24 h Urinary Excretion in a Healthy Mexican Cohort. 2017, 48, doi:10.1016/j.arcmed.2017.03.012.

He, F.J.; MacGregor, G.A. Beneficial effects of potassium on human health. Physiol. Plant. 2008, 133, 725-735, doi:10.1111/j.13993054.2007.01033.x. 
15, 694-702, doi:10.1007/s11906-013-0390-z.

19. Organización Panamerica de la Salud. SHAKE menos sal, más salud. Guía técnica para reducir el consumo de sal.; Washington, D.C., 2018;

20. Cook, N.R.; Obarzanek, E.; Cutler, J.A.; Buring, J.E.; Rexrode, K.M.; Kumanyika, S.K.; Appel, L.J.; Whelton, P.K. Joint effects of sodium and potassium intake on subsequent cardiovascular disease: the Trials of Hypertension Prevention follow-up study. Arch. Intern. Med. 2009, 169, 32-40, doi:10.1001/archinternmed.2008.523.

21. O'Donnell, M.; Mente, A.; Rangarajan, S.; McQueen, M.J.; O’Leary, N.; Yin, L.; Liu, X.; Swaminathan, S.; Khatib, R.; Rosengren, A.; et al. Joint association of urinary sodium and potassium excretion with cardiovascular events and mortality: Prospective cohort study. BMJ 2019, 364, 1-14, doi:10.1136/bmj.1772.

O’Donnell, M.; Mente, A.; Rangarajan, S.; McQueen, M.J.; Wang, X.; Liu, L.; Yan, H.; Lee, S.F.; Mony, P.; Devanath, A.; et al. Urinary sodium and potassium excretion, mortality, and cardiovascular events. N. Engl. J. Med. 2014, 371, 612-623, doi:10.1056/NEJMoa1311889.

23. Romero-Martínez, M.; Shamah-Levy, T.; Cuevas-Nasu, L.; Méndez Gómez-Humarán, I.; Gaona-Pineda, E.; Gómez-Acosta, L.; Rivera-Dommarco, J. Diseño metodológico de la Encuesta Nacional de Salud y Nutrición de Medio Camino 2016. Salud Publica Mex 2017, 59, 299-305, doi:http://doi.org/10.21149/8593.

Blanton, C.A.; Moshfegh, A.J.; Baer, D.J.; Kretsch, M.J. The USDA Automated Multiple-Pass Method accurately estimates group total energy and nutrient intake. J. Nutr. 2006, 136, 2594-2599, doi:10.1093/jn/136.10.2594.

López-Olmedo, N.; Carriquiry, A.L.; Rodríguez-Ramírez, S.; Ramírez-Silva, I.; Espinosa-Montero, J.; Hernández-Barrera, L.; Campirano, F.; Martínez-Tapia, B.; Rivera, J.A. Usual Intake of Added Sugars and Saturated Fats Is High while Dietary Fiber Is Low in the Mexican Population. J. Nutr. 2016, 146, 1856S-1865S, doi:10.3945/jn.115.218214.

Ramírez Silva I, Rivera J, Barragán S, Barquera S, Tolentino L, R.S. Base de Alimentos de México (BAM): Compilación de la composición de los alimentos frecuentemente consumidos en el país. Versión 1.1.; Morelos, México, 2019;

Monteiro, C.A.; Cannon, G.; Levy, R.; Moubarac, J.-C.; Jaime, P.; Martins, A.P.; Canella, D.; Louzada, M.; Parra, D. NOVA. The Star Shines Bright (Food Classification. Public Health). World Nutr. 2016, 7, 28-38.

Marrón-Ponce, J.A.; Flores, M.; Cediel, G.; Monteiro, C.A.; Batis, C. Associations between Consumption of Ultra-Processed Foods and Intake of Nutrients Related to Chronic Non-Communicable Diseases in Mexico. J. Acad. Nutr. Diet. 2019, 119, 1852-1865, doi:10.1016/j.jand.2019.04.020.

29. Vyas, S.; Kumaranayake, L. Constructing socio-economic status indices: How to use principal components analysis. Health Policy Plan. 2006, 21, 459-468, doi:10.1093/heapol/czl029.

WHO Expert Committee on Physical Status : the Use and Interpretation of Anthropometry (1993 : Geneva, S.; Organization, W.H. Physical status : the use of and interpretation of anthropometry, report of a WHO expert committee 1995.

Pickering, T.G.; Hall, J.E.; Appel, L.J.; Falkner, B.E.; Graves, J.; Hill, M.N.; Jones, D.W.; Kurtz, T.; Sheps, S.G.; Roccella, E.J. Recommendations for blood pressure measurement in humans and experimental animals: part 1: blood pressure measurement in humans: a statement for professionals from the Subcommittee of Professional and Public Education of the American Heart Association Co. Circulation 2005, 111, 697-716, doi:10.1161/01.CIR.0000154900.76284.F6.

ADA, A.D.A. Classification and Diagnosis of Diabetes : Standards of Medical Care in Diabetes - 2020. Diabetes Care 2020, 43, 1431, doi:10.2337/dc20-S002.

34. Levey, A.S.; Stevens, L.A.; Schmid, C.H.; Zhang, Y.L.; Castro, A.F. 3rd; Feldman, H.I.; Kusek, J.W.; Eggers, P.; Van Lente, F.; Greene, T.; et al. A new equation to estimate glomerular filtration rate. Ann. Intern. Med. 2009, 150, 604-612, doi:10.7326/00034819-150-9-200905050-00006.

35. Carrillo-Larco, R.M.; Bernabe-Ortiz, A. Sodium and Salt Consumption in Latin America and the Caribbean: A Systematic-Review and Meta-Analysis of Population-Based Studies and Surveys. Nutrients 2020, 12, doi:10.3390/nu12020556.

Powles, J.; Fahimi, S.; Micha, R.; Khatibzadeh, S.; Shi, P.; Ezzati, M.; Engell, R.E.; Lim, S.S.; Danaei, G.; Mozaffarian, D. Global, regional and national sodium intakes in 1990 and 2010: a systematic analysis of 24 h urinary sodium excretion and dietary surveys worldwide. BMJ Open 2013, 3, e003733, doi:10.1136/bmjopen-2013-003733.

37. Kumssa, D.B.; Joy, E.J.M.; Broadley, M.R. Global Trends (1961-2017) in Human Dietary Potassium Supplies. Nutrients 2021, 13, doi:10.3390/nu13041369.

38. Pereira, T.S.S.; Cade, N.V.; Mill, J.G.; Sichieri, R.; Molina, M.D.C.B. Use of the Method of Triads in the Validation of Sodium and Potassium Intake in the Brazilian Longitudinal Study of Adult Health (ELSA-Brasil). PLoS One 2016, 11, e0169085, doi:10.1371/journal.pone.0169085. 
Public Health Nutr. 2002, 5, 947-953, doi:10.1079/phn2002370.

40. Popkin, B.M. The Nutrition Transition: An Overview of World Patterns of Change. Nutr. Rev. 2004, 62, doi:10.1301/nr.2004.jul.S140-S143.

41. Popkin, B.M.; Adair, L.S.; Ng, S.W. Global nutrition transition and the pandemic of obesity in developing countries. Nutr. Rev. 2012, 70, 3-21, doi:10.1111/j.1753-4887.2011.00456.x.

42. García-chávez, C.G.; Monterrubio-flores, E.; Ramírez-silva, I.; Aburto, T.C.; Pedraza, L.S.; Rivera-dommarco, J. Contribución de los alimentos a la ingesta total de energía en la dieta de los mexicanos mayores de cinco años. Salud Publica Mex. 2020, 62.

Micha, R.; Khatibzadeh, S.; Shi, P.; Andrews, K.G.; Engell, R.E.; Mozaffarian, D. Global, regional and national consumption of major food groups in 1990 and 2010: a systematic analysis including 266 country-specific nutrition surveys worldwide. BMJ Open 2015, 5, e008705, doi:10.1136/bmjopen-2015-008705. Insitute for Health Metrics and Evaluation (IHME) Global Burden Disease Compare Data Visualization.; Seattle, WA: IHME, 2019; Moubarac, J.-C.; Batal, M.; Louzada, M.L.; Martinez Steele, E.; Monteiro, C.A. Consumption of ultra-processed foods predicts diet quality in Canada. Appetite 2017, 108, 512-520, doi:https://doi.org/10.1016/j.appet.2016.11.006.

Machado, P.P.; Steele, E.M.; Levy, R.B.; Sui, Z.; Rangan, A.; Woods, J.; Gill, T.; Scrinis, G.; Monteiro, C.A. Ultra-processed foods and recommended intake levels of nutrients linked to non-communicable diseases in Australia: evidence from a nationally representative cross-sectional study. BMJ Open 2019, 9, e029544, doi:10.1136/bmjopen-2019-029544.

Schnabel, L.; Kesse-Guyot, E.; Allès, B.; Touvier, M.; Srour, B.; Hercberg, S.; Buscail, C.; Julia, C. Association Between Ultraprocessed Food Consumption and Risk of Mortality Among Middle-aged Adults in France. JAMA Intern. Med. 2019, 179, 490-498, doi:10.1001/jamainternmed.2018.7289.

48. Cuadrado-Soto, E.; Peral-Suarez, Á.; Aparicio, A.; Perea, J.M.; Ortega, R.M.; López-Sobaler, A.M. Sources of Dietary Sodium in Food and Beverages Consumed by Spanish Schoolchildren between 7 and 11 Years Old by the Degree of Processing and the Nutritional Profile. Nutrients 2018, 10, doi:10.3390/nu10121880.

Rauber, F.; da Costa Louzada, M.L.; Steele, E.M.; Millett, C.; Monteiro, C.A.; Levy, R.B. Ultra-Processed Food Consumption and Chronic Non-Communicable Diseases-Related Dietary Nutrient Profile in the UK (2008-2014). Nutrients 2018, 10, doi:10.3390/nu10050587.

50. Thuesen, B.H.; Toft, U.; Buhelt, L.P.; Linneberg, A.; Friedrich, N.; Nauck, M.; Wallaschofski, H.; Jørgensen, T. Estimated daily salt intake in relation to blood pressure and blood lipids: the role of obesity. Eur. J. Prev. Cardiol. 2015, 22, 1567-1574, doi:10.1177/2047487314553201.

51. Koyama, T.; Yoshiike, N. Association between Parent and Child Dietary Sodium and Potassium Intakes: Aomori Prefectural Health and Nutrition Survey, 2016. Nutrients 2019, 11, doi:10.3390/nu11061414.

Merkiel, S.; Chalcarz, W. Preschool diets in children from Piła, Poland, require urgent intervention as implied by high risk of nutrient inadequacies. J. Health. Popul. Nutr. 2016, 35, 11, doi:10.1186/s41043-016-0050-4.

53. O'Halloran, S.A.; Grimes, C.A.; Lacy, K.E.; Campbell, K.J;; Nowson, C.A. Dietary intake and sources of potassium and the relationship to dietary sodium in a sample of Australian pre-school children. Nutrients 2016, 8, doi:10.3390/nu8080496.

Rodríguez-Ramírez, S.; Muñoz-Espinosa, A.; Rivera, J.A.; González-Castell, D.; González de Cosío, T. Mexican Children under 2 Years of Age Consume Food Groups High in Energy and Low in Micronutrients. J. Nutr. 2016, 146, 1916S-1923S, doi:10.3945/jn.115.220145.

Farapti, F.; Sulistyowati, M.; Artanti, K.D.; Setyaningtyas, S.W.; Sumarmi, S.; Mulyana, B. Highlighting of Urinary Sodium and Potassium among Indonesian Schoolchildren Aged 9-12 Years: The Contribution of School Food. J. Nutr. Metab. 2019, 2019, 1028672, doi:10.1155/2019/1028672.

56. López-Sobaler, A.M.; Aparicio, A.; González-Rodríguez, L.G.; Cuadrado-Soto, E.; Rubio, J.; Marcos, V.; Sanchidrián, R.; Santos, S.; Pérez-Farinós, N.; Dal Re, M.Á.; et al. Adequacy of Usual Vitamin and Mineral Intake in Spanish Children and Adolescents: ENALIA Study. Nutr. 2017, 9.

Saeid, N.; Elmzibri, M.; Hamrani, A.; Latifa, Q.; Belghiti, H.; El Berri, H.; Benjeddou, K.; Bouziani, A.; Benkirane, H.; Taboz, Y.; et al. Assessment of Sodium and Potassium Intakes in Children Aged 6 to 18 Years by $24 \mathrm{~h}$ Urinary Excretion in City of Rabat, Morocco. J. Nutr. Metab. 2018, 2018, 8687192, doi:10.1155/2018/8687192.

Grimes, C.A.; Riddell, L.J.; Campbell, K.J.; Beckford, K.; Baxter, J.R.; He, F.J.; Nowson, C.A. Dietary intake and sources of sodium and potassium among Australian schoolchildren: results from the cross-sectional Salt and Other Nutrients in Children (SONIC) study. BMJ Open 2017, 7, e016639, doi:10.1136/bmjopen-2017-016639.

59. Gonçalves, C.; Abreu, S.; Padrão, P.; Pinho, O.; Graça, P.; Breda, J.; Santos, R.; Moreira, P. Sodium and potassium urinary excretion and dietary intake: a cross-sectional analysis in adolescents. Food Nutr. Res. 2016, 60, 29442, doi:10.3402/fnr.v60.29442. 
Nutr. 2018, 27, 1106-1119, doi:10.6133/apjcn.042018.02.

61. O'Neil, C.E.; Nicklas, T.A.; Fulgoni, V.L. 3rd Food Sources of Energy and Nutrients of Public Health Concern and Nutrients to Limit with a Focus on Milk and other Dairy Foods in Children 2 to 18 Years of Age: National Health and Nutrition Examination Survey, 2011-2014. Nutrients 2018, 10, doi:10.3390/nu10081050.

62. Zárate-Ortiz, A.G.; Melse-Boonstra, A.; Rodríguez-Ramírez, S.; Hernández-Cordero, S.; Feskens, E.J.M. Dietary Patterns and the Double Burden of Malnutrition in Mexican Adolescents: Results from ENSANUT-2006. Nutrients 2019, 11, doi:10.3390/nu11112753.

63. Huang, L.; Wang, H.; Wang, Z.; Wang, Y.; Zhang, B.; Ding, G. Associations of dietary sodium, potassium, and sodium to potassium ratio with blood pressure - regional disparities in China. Nutrients 2020, 12, doi:10.3390/nu12020366.

64. Bolton, K.A.; Trieu, K.; Woodward, M.; Nowson, C.; Webster, J.; Dunford, E.K.; Bolam, B.; Grimes, C. Dietary Intake and Sources of Potassium in a Cross-Sectional Study of Australian Adults. Nutrients 2019, 11, doi:10.3390/nu11122996.

65. Sharma, S.; McFann, K.; Chonchol, M.; Kendrick, J. Dietary sodium and potassium intake is not associated with elevated blood pressure in US adults with no prior history of hypertension. J. Clin. Hypertens. (Greenwich). 2014, 16, 418-423, doi:10.1111/jch.12312.

66. Colin-Ramirez, E.; Espinosa-Cuevas, Á.; Miranda-Alatriste, P.V.; Tovar-Villegas, V.I.; Arcand, J.; Correa-Rotter, R. Food sources of sodium intake in an adult mexican population: A sub-analysis of the SALMEX study. Nutrients 2017, 9, 1-13, doi:10.3390/nu9080810.

67. Fang, K.; He, Y.; Fang, Y.; Lian, Y. Dietary Sodium Intake and Food Sources Among Chinese Adults: Data from the CNNHS 2010-2012. Nutrients 2020, 12, doi:10.3390/nu12020453.

68. Secretaria de Salud [SSA] Norma Oficial Mexicana -043-SSA2-2012, Servicios básicos de salud. Promoción y educación para la salud en materia alimentaria. Criterios para brindar orientación. Available online: http://www.dof.gob.mx/nota_detalle.php?codigo=5285372\&fecha=22/01/2013. 